NBER WORKING PAPER SERIES

\title{
REVISITING AMERICAN EXCEPTIONALISM: DEMOCRACY AND THE REGULATION OF CORPORATE GOVERNANCE IN NINETEENTH-CENTURY PENNSYLVANIA
}

\author{
Naomi R. Lamoreaux \\ Working Paper 20231 \\ http://www.nber.org/papers/w20231 \\ NATIONAL BUREAU OF ECONOMIC RESEARCH \\ 1050 Massachusetts Avenue \\ Cambridge, MA 02138 \\ June 2014
}

This paper builds on collaborative work with Timothy Guinnane, Ron Harris, and Jean-Laurent Rosenthal. I am grateful for the comments of Jeremy Atack, Margaret Blair, William Collins, Stanley Engerman, Louis Galambos, Carl Gershenson, Timothy Guinnane, Leslie Hannah, Robert Margo, Eric Rasmusen, an anonymous referee, participants in the NBER-Vanderbilt conference on "Enterprising America," the University of California, Santa Barbara Symposium on "The New History of Capitalism," and the Harvard Workshop in History, Culture, and Society. Thanks too to Guillaume Frencia, Sasha Nichols Geerdes, Thao Nguyen, and Erinn Wong for their able research assistance and to the National Science Foundation, the University of California, Los Angeles, and Yale University for financial support. The views expressed herein are those of the author and do not necessarily reflect the views of the National Bureau of Economic Research.

NBER working papers are circulated for discussion and comment purposes. They have not been peerreviewed or been subject to the review by the NBER Board of Directors that accompanies official NBER publications.

(C) 2014 by Naomi R. Lamoreaux. All rights reserved. Short sections of text, not to exceed two paragraphs, may be quoted without explicit permission provided that full credit, including $\mathbb{C}$ notice, is given to the source. 
Revisiting American Exceptionalism: Democracy and the Regulation of Corporate Governance in Nineteenth-Century Pennsylvania

Naomi R. Lamoreaux

NBER Working Paper No. 20231

June 2014, Revised October 2014

JEL No. K2,N41

\section{ABSTRACT}

The legal rules governing businesses' organizational choices have varied across nations along two main dimensions: the number of different forms that businesses can adopt; and the extent to which businesses have the contractual freedom to modify the available forms to suit their needs. Until the late twentieth century, businesses in the U.S. had a narrower range of forms from which to choose than their counterparts in these other countries and also much less ability to modify the basic forms contractually. This article uses the case of Pennsylvania to argue that the sources of this "American exceptionalism" reside in the interplay between the early achievement of universal (white) manhood suffrage and elite efforts to safeguard property rights.

Naomi R. Lamoreaux

Department of Economics

Yale University

27 Hillhouse Ave., Rm. 39

Box 208269

New Haven, CT 06520-8269

and NBER

naomi.lamoreaux@yale.edu 


\section{Revisiting American Exceptionalism}

\section{Introduction}

The idea of American exceptionalism, particularly the notion that American institutions should be held up as a model to the rest of the world, has fallen out of favor among historians in recent decades. The idea had its roots in the Puritans' vision of their settlement in the Massachusetts Bay Colony as a "city on the hill” and in early-nineteenth-century Americans' belief in their "manifest destiny" (Murrin 2000, Onuf 2012). Writing in the late nineteenth century, historians George Bancroft and Frederick Jackson Turner transformed this belief into a story of the growth of democracy and the spread of liberty (Ross 1984, Tyrrell 1991). Although there was always a counter narrative that emphasized the limits of this achievement and the extent to which progress depended on hard-fought struggles waged by those on the bottom of society, the idea of American exceptionalism retained considerable influence on historical writing through much of the twentieth century. More recently, however, historians have stressed the dark side of these trends, in particular the extent to which increases in the rights and status enjoyed by common white men came at the expense of women, blacks, native peoples, and immigrants. As a result, the notion that we should study American history for lessons that other countries might profitably emulate has largely disappeared from historical writing, although the idea continues to exert considerable hold on the popular imagination (Tyrrell 1991).

Economists are more likely than historians to hold the United States up as a model for the world to emulate, though they do not typically use the language of American exceptionalism. Instead, they discuss the American advantage as the product of a set of measurable characteristics that quantitative analysis (mainly in the form of cross-country regressions) has 
shown to be significantly related to economic performance. These characteristics include geographic factors that are largely outside history (such as climate or topography); institutional or cultural characteristics that, though they are products of history, generally are taken as givens (such as a country's ethnic or religious makeup); and institutional or cultural variables that, though they are products of history, could at least in theory be adopted by any country (such as democratic elections or a free press). ${ }^{1}$ It is mainly this last category that leads economists to treat U.S. institutions as the standard to which other countries should aspire.

Cross-country regressions, however, are at best crude analytical tools. The need to collect the same types of measures for a large sample of countries means that key variables must often be represented by highly imperfect proxies. Moreover, there is often an element of circularity in the choice of explanatory variables. Scholars start with knowledge of which countries are successful, pick variables that contemporary observation would suggest are causally associated with that success, and then see if the correlations withstand further scrutiny. But here they encounter the further problem that many of the variables that they hypothesize are important for economic development might also be endogenous products of that development or of other circumstances causally related to it. To deal with that possibility, economists search for some other variable that allows them to isolate causation — an "instrument" that is plausibly exogenous and related to economic development only through the posited channel. That search typically leads to a measure that is either outside of history completely, such as a geographic indicator, or outside the historical processes being analyzed because it long predated them. What then all too frequently happens is that these "instruments" irresistibly become explanations in and of

\footnotetext{
${ }^{1}$ The literature is voluminous, but see for examples Barro (1997); Barro and McCleary (2003); McCleary and Barro (2006); Bloom and Sachs (1998); Gallup, Sachs and Mellinger (1999); Sachs and Warner (2001); Acemoglu, Johnson, and Robinson (2001); Rodrik, Subramanian, and Trebbi (2004); Papaioannou and Siourounis (2008). For an approach that does not involve cross-country regressions, see Engerman and Sokoloff (2011).
} 
themselves, and the channels they were supposed to help identify fade into the background. ${ }^{2}$ The result has been a flurry of "historical" studies in which history itself plays little or no role.

Instead, these studies emphasize the persistent effects of the instrumental variable and treat what happened in the intervening centuries as if it were of little consequence. ${ }^{3}$

The larger purpose of this essay is to argue that we ignore the intervening history at our peril. To make this case I focus on the history of the law of business organizational forms, particularly the corporation. Studies based on cross-country regressions have argued that AngloAmerican common law is much more conducive to financial development than the code-based legal systems of the European continent, particularly those modeled on the French code. ${ }^{4}$ I show, to the contrary, that corporate law in the U.S. until recently was fundamentally different from that in the other major common-law country, Great Britain, which had more in common with the law on the European continent. The different character of business law in the U.S., I would like to propose, was related to characteristics that have been traditionally considered markers of U.S. exceptionalism, particularly the early achievement of universal (white) manhood suffrage. In Britain and on the European continent, general incorporation laws were enacted long before the expansion of the suffrage, which meant that they were largely written by and in the interests of the business people who would use them. By contrast, in the U.S. the expansion of the suffrage came much earlier. The various state legislatures wrote their general incorporation laws in the context, on the one hand, of a mass political movement aimed at preventing "the moneyed few" from using the corporate form to gain unfair economic advantages and, on the other, of efforts by the elite to prevent democratically elected legislators

\footnotetext{
${ }^{2}$ On this point, see especially Rodrik, Subramanian, and Trebbi (2004).

${ }^{3}$ Examples include Nunn (2008), Nunn and Wantchekon (2011), Alesina, Giuliano, and Nunn (2013).

${ }^{4}$ See especially La Porta, et al. (1997 and 1998). These articles sparked an enormous literature that has been surveyed in La Porta, Lopez-de-Silanes, and Shleifer (2008); and Roe and Siegel (2009).
} 
from tampering with property rights. How these countervailing pressures played out on the ground varied from one state to the next but as a general rule they resulted in significant restrictions on the use of the corporation and related forms.

Although it might be tempting to think of the extension of the franchise as another initial condition that could be added to cross-country regressions, this essay aims to document the importance of ongoing historical processes in shaping the law of business organizational forms. To this end, after setting up the general context, this essay focuses on the experience of Pennsylvania, where democratic politics kept the state's general incorporation laws remarkably restrictive, and where creditor-oriented (pro-property rights) courts hamstrung an effort to create an early version of a limited liability company (LLC). It focuses in particular on the latter third of the nineteenth century in order to emphasize the importance of moving beyond initial conditions to examine the interaction of democratic politics and business needs. The paper then returns to the general context, comparing developments in Pennsylvania with those in other states and drawing out the implications of these parallel histories for our understanding of U.S. exceptionalism. The case of Delaware in particular highlights the importance of looking beyond initial conditions. Delaware started out on much the same path as Pennsylvania, and by the middle of the nineteenth century its corporate law had moved in an even more restrictive direction. Only at the very end of the century, when New Jersey's liberalization of its general incorporation laws sparked a national charter-mongering competition, did Delaware shift to a different path and enact the more permissive law for which the state is famous. Although other states then began to copy Delaware's example, convergence was much slower than is generally realized. Moreover, as late as the 1950s, even in Delaware U.S. law was still much more prescriptive than its British counterpart. Visiting at Harvard during that decade, the prominent 
British company-law specialist L. C. B. Gower was stunned to observe that although British law is "essentially contractual[,] ... the American statutes tend to lay down mandatory rules" (Gower $1956,1376)$.

There was no single, archetypal American story of the development of business institutions in the nineteenth century. Rather, there was a Pennsylvania story, a Delaware story, a New Jersey story, a Massachusetts story, an Ohio story, a Virginia story, a California story, and so on. ${ }^{5}$ Nonetheless, as I argue in this essay, the conflict over elite privileges versus property rights that resulted from the early expansion of the franchise drove the evolution of business organizational forms throughout the United States in broadly similar ways. The trick to getting the history right is to understand how different local manifestations of essentially the same initial conditions interacted with each other to shape the path of institutional change.

\section{The Distinctive Character of the Corporate Form in the United States}

Virtually everywhere in the world in the early nineteenth century, business people could only form corporations with the specific authorization of the state, which meant that those who were closely connected with the ruling elite had privileged access to the form. By the end of the century, however, in the U.S. and most Western European countries access to the corporate form had been opened up, so that almost anyone who wanted to could form a business corporation by a simple process of registration (North, Wallis, and Weingast 2009; Lamoreaux and Wallis 2012). General incorporation came somewhat later to the European continent than to England and the U.S, but that was largely because the Napoleonic code enabled businesses to achieve some of the benefits of incorporation in other ways (Lamoreaux and Rosenthal 2005, Guinnane,

\footnotetext{
${ }^{5}$ One important implication of this argument is that we need a new generation of state-level studies of the corporate form such as the one by Eric Hilt in this volume.
} 
et al. 2007). For example, in France and other countries that adopted Napoleonic law, business people could form limited partnerships in which the general partners bore unlimited liability but the limited partners risked only their investments. Limited partnerships could even have tradable shares, making them reasonable substitutes for corporations. In Britain, by contrast, the only alternative to the corporation that multi-owner enterprises could employ was the ordinary partnership in which all members were unlimitedly liable. In the U.S., most states passed laws in the early nineteenth century allowing businesses to organize limited partnerships, but the form never became widespread because creditor-oriented courts interpreted the law in ways that increased the risk that limited partners would be found unlimitedly liable (Lamoreaux and Rosenthal 2005, Guinnane, et al. 2007). ${ }^{6}$

Although in both Britain and the United States the lack of alternatives to the ordinary partnership increased demand for the corporate form, the political contexts in which two countries enacted their general incorporation laws were very different, and as a result the statutes were poles apart in the way they functioned. In Britain, the Reform Act of 1832 had shifted representation in Parliament in favor of cities (and hence business interests) without dramatically expanding the franchise, so still less than half of adult males were formally eligible to vote and less than 10 percent actually voted (Flora et al. 1983, O’Gorman 1993, Phillips and Wetherell 1995). When Parliament finally responded to the pent up demand for corporate charters by passing a general enabling law, it was mainly the people involved in organizing and financing companies who shaped the content of the legislation. ${ }^{7}$ The first statute, passed in 1844 , protected

\footnotetext{
${ }^{6}$ In France, moreover, even ordinary partners could control the extent of their liabilities by writing contracts that restricted partners' ability to encumber the firm without the explicit approval of the other partners. Under the Napoleonic Code, such agreements were fully enforceable so long as they were registered. Under the British or American common law, by contrast, they were not enforceable against third parties that had not been notified in advance about their terms. See Lamoreaux and Rosenthal (2005).

${ }^{7}$ On the transition to general incorporation in Britain, see Harris (2000), Taylor (2006), and Freeman, Pearson and Taylor (2011).
} 
investors' interests by making shareholders unlimitedly liable for their corporation's debts.

Otherwise, however, it treated the relationship between a company's organizers and investors as contractual. The law provided companies with a basic governance template, but permitted incorporators to add any "provisions for such other purposes (not inconsistent with Law) as the parties to such Deed shall think proper." ${ }^{\prime 8}$ When Parliament passed additional legislation in 1855 and 1856, making it possible for companies to opt for limited liability, it increased the extent of incorporators' contractual freedom by replacing the basic template with a set of default governance rules included in a table appended to the act (Thring 1856). This table was formalized in the Companies Act of 1862 as Table A. If a company did not submit its own articles of association at the time of registration, the detailed governance rules in Table A applied. But a company could reject any or all of the clauses of the table and write its own rules from scratch. The only governance rules that the law mandated were that the company hold a general meeting at least once a year and that the articles of association be amendable by a threequarters vote of the shareholders (Guinnane, Harris, and Lamoreaux 2014). ${ }^{9}$

The contractual flexibility that characterized British company law contrasted sharply with the much more prescriptive statutes passed by the various U.S. states around the same time (Gower 1956, Harris and Lamoreaux 2010). These statutes were enacted in the very different political environment produced by the early achievement of nearly universal manhood suffrage. In the decades following independence, state governments had faced insistent demands to provide their citizens with the infrastructure needed for economic development, from transportation improvements to financial services. The same citizens did not want to pay taxes,

\footnotetext{
${ }^{8}$ Companies Act 1844 7\&8 Vict. C. 110 Section VII.

${ }^{9}$ British law set the minimum number of incorporators at seven, but in many closely held companies at least some of the seven were nominal. This practice was upheld by the House of Lords in Salomon v. A. Salomon and Co. Ltd (1897) AC 22.
} 
however, so states solved the problem of financing such projects by granting corporate charters to private groups that promised to undertake them in their stead (Seavoy 1982, Majewski 2000). These charters usually included an array of special privileges, sometimes as inducements to invest in projects of uncertain profitability and sometimes in response to the lobbying of politically well-connected incorporators. ${ }^{10}$ Charters for turnpike, bridge, and canal companies typically conveyed a monopoly right to levy tolls, as well powers of eminent domain. Perks granted to incorporators of the Society for Useful Manufactures (SUM), a textile company chartered in New Jersey in 1791, included permission to raise funds through a public lottery and exemptions for the company's employees from taxes and military service (except in the case of invasion) (Maier 1993). Bank charters conveyed the right to issue currency in the form of bank notes (Handlin and Handlin 1969, Lamoreaux 1994). This latter privilege turned out to be so valuable that control of entry into banking became an important way of solidifying political power in the years following the American Revolution. Whichever party dominated the legislature kept tight control of bank charters, awarding them exclusively to prominent political supporters (Lu and Wallis 2013, Bodenhorn 2006).

The boons that legislatures awarded to recipients of corporate charters generated a tremendous amount of resentment, most obviously among the members of the general population who bore the cost, but also among entrepreneurs seeking the chance to compete away some of the monopoly rents. As corporations became a lightning rod for political discontent, some states passed constitutional amendments that imposed outright bans on chartering certain types of corporations. In other states, however, legislatures began instead to liberalize their chartering policies. In Massachusetts, for example, the General Court responded to popular pressure by

\footnotetext{
${ }^{10}$ Political officials were often large shareholders in early corporations. See, for example, Hilt and Valentine (2012) on New York.
} 
handing out charters to rival interests. In 1828, it granted a charter of incorporation to a company that proposed to build a bridge over the Charles River right next to one that had been awarded the original monopoly (Kutler 1971). It also granted numerous charters for banks in competition with existing financial institutions - so many, in fact, that when the state finally passed a general incorporation law in 1851, almost no banks organized under it (Lamoreaux 1994, Lu and Wallis 2013).

In most states, however, popular pressure led directly to the passage of general incorporation laws. When the political turmoil that followed the Panic of 1837 dislodged New York's Democratic political machine (the Albany Regency) from power, the legislature passed the first "free banking" act (Bodenhorn 2006). A number of other states soon passed similar legislation, and the New York statute subsequently became the model for the National Banking Acts passed by the U.S. Congress during the Civil War (Bodenhorn 2002). Even earlier, New York had enacted the first general incorporation act for manufacturing as a way of encouraging domestic industry during the run-up to the War of 1812, but few states followed suit until the late 1840s. The Panic of 1837 and the depression that followed a second major financial crisis in 1839 led a number of states to default on their debts. The political realignments that followed led to major constitutional reforms and also to the spread of general incorporation laws, so that by 1860 the vast majority (27 out of 32 ) states and territories had enacted them for manufacturing (Hilt 2013, Wallis 2005, Hurst 1970).

Not surprisingly, given this political context, most of the early general incorporation laws imposed strict limits on what corporations could do, how big they could grow, how long they could last, and what forms their internal governance could take. The extent of these regulations varied from state to state (see Table 1). Ohio’s 1846 law, Massachusetts's 1851 statute, and 
Illinois's 1857 act all put ceilings on the amount of capital a corporation could raise, but neither New York’s 1848 statute nor Pennsylvania’s 1849 law imposed such a limit. Pennsylvania set the term of a corporate charter at 20 years, Ohio at 40 years, and New York and New Jersey 50 years, while Massachusetts allowed corporations perpetual life. All of these states except Ohio limited the amount of debt that corporations could take on to some multiple of their capital stock (usually one). Pennsylvania had the most generous multiple, but it severely restricted the amount of real estate that corporations could own. The Massachusetts and New Jersey statutes did not specify a voting rule for shareholders, but New York, Ohio, and Pennsylvania mandated one share one vote, and Pennsylvania added a restriction that no shareholder could vote more than a third of the total number of shares. The laws generally prescribed the number of directors, sometimes requiring them to be shareholders and/or citizens of the state. The statutes often also imposed additional liabilities on shareholders under specified circumstances.

The flip side of this democratic concern about corporate privileges was elites' anxiety about the security of their property rights. From the nation's earliest years, James Madison and other prominent political leaders had worried that if the poor had political power, they would use it to redistribute property from the rich (Nedelsky 1990). As late as 1821 , in a speech to New York's constitutional convention, Chancellor James Kent had opposed abolishing property qualifications for voting for state senators on the grounds that " $\mathrm{t}]$ he tendency of universal suffrage is to jeopardize the rights of property, and the principles of liberty." It was human nature, Kent declared, for the poor to covet the wealth of the rich, the debtor to wish to avoid the obligation of contracts, and "the indolent and the profligate to cast the whole burthens of society upon the industrious and virtuous." Democratic politics provided "ambitious and wicked men" with the opportunity "to inflame these combustible materials," so it was critical to preserve at 
least one branch of the legislature "as the representative of the landed interest" (New York 1821, 221). Legislatures were already bowing to popular demands to the disadvantage of the wealthy, enacting stay laws to protect debtors from foreclosure during financial crises and passing adverse possession laws that made it easier for squatters to claim the property of landowners who had legitimate titles (Hartz 1848, Gates 1962, Aron 1992, de Soto 2000, Balleisen 2001, Van Atta 2008). ${ }^{11}$ Expanding the franchise, conservatives like Kent worried, would only make the problem worse.

Legislatures also responded to popular pressures by reneging on privileges that earlier bodies had imbedded in corporate charters. In Massachusetts, for example, complaints that the original 1784 charter of the Massachusetts Bank was too expansive led the General Court to pass an "Addition" in 1792 that placed greater limits on the bank's operations (Maier 1992). The Virginia legislature intervened in a dispute between urban and rural members of the incorporated Mutual Assurance Society against Fires on Buildings, passing an act in 1800 dictating that legislators would represent absent members at general meetings. With the assistance of these legislative representatives, the country members were able to reorganize the company so that it better suited their interests (Campbell 1975). After the Virginia assembly chartered the Richmond James River Company in 1804, a deluge of complaints led the legislature to amend the charter and, over the objections of the company, exempt small boats from having to pay tolls (Campbell 1975).

The Supreme Court temporarily put a stop to such actions when Chief Justice John Marshall's famously declared in Dartmouth College v. Woodward (1819) ${ }^{12}$ that a corporate

\footnotetext{
${ }^{11}$ It should be noted, however, that elite owners of mills, mines, and transportation companies also used their influence in legislatures to take property from farmers and other small holders using eminent domain proceedings. See Lamoreaux (2011).

${ }^{12}$ Dartmouth College v. Woodward, 17 U.S. 518 (1819).
} 
charter was a contract that the state could not unilaterally abrogate, but legislatures quickly learned to imbed reservation clauses in charters that gave them the authority to alter the terms at will (Hartz 1948, Wells 1886). Moreover, under the leadership of Chief Justice Roger Taney, a Jacksonian Democrat, the Court moved to construe corporate charters in the narrowest possible terms. When the Massachusetts legislature authorized the construction of the second bridge across the Charles River at Charlestown, proprietors of the original Charles River Bridge sued to block construction. In the words of their attorney Warren Dutton, chartering the new bridge was "an act of confiscation" that threatened "all sense of security for the rights of persons and property."13 Similarly, Justice Joseph Story warned that if the proprietors had foreseen "such a total insecurity of all rights of property" as the legislature's actions signified, "the project would have been dropped, still born," and the growth in commerce that the bridge had made possible would never have occurred. ${ }^{14}$

These arguments did not carry the day in the Charles River Bridge case, but wherever and whenever they could, conservative jurists used the power of the courts to protect the rights of creditors and of property holders more generally. One important consequence of these efforts was to compress further the menu of organizational forms available to business enterprises. As already noted, the Napoleonic code enabled French entrepreneurs to organize limited partnerships, but English common law did not permit an equivalent form. In an early attempt to reduce the extent of the privileges associated with the corporate form, most of the U.S. states passed enabling statutes for limited partnerships during the 1820s and 1830s (Kessler 2003, Hilt

\footnotetext{
${ }^{13}$ Charles River Bridge v. Warren Bridge, 36 U.S. 420 (1837). The quotation is from pp. $73-74$ of the 1837 U.S. LEXIS 180 edition of the case.

${ }^{14}$ Charles River Bridge v. Warren Bridge, 36 U.S. 420 at 615. Taney in turn justified his decision against the monopoly with the claim that it was necessary for economic development. He conjured up a nightmarish vision of proprietors of old turnpike corporations "awakening from their sleep" to claim similar rights, putting in jeopardy "the millions of property which have been invested in railroads and canals" along adjacent routes. See pp. $552-53$. For an extended analysis of this case, see Kutler (1971).
} 
and O'Banion 2009). The courts soon eviscerated these statutes, however, interpreting them, in their zeal to protect creditors, in ways that potentially exposed limited partners to liability. For example, judges gave notice that they would view deviations from the declarations contained in the partnership certificate as sufficient cause to hold all of the partners unlimitedly liable for the firm's debts - even partners who were innocent of error, and even if the substance of the deviation was inconsequential (Lewis 1917; Warren 1929, Ch.6; Howard 1934). Not surprisingly, the form was used much more rarely in the United States than in France or elsewhere on the European continent. ${ }^{15}$ The end result of the political battles of the early nineteenth century, therefore, was that business people in the U.S. had much less contractual flexibility in the way they could use the corporate form and also an effectively smaller menu of organizational forms than their counterparts in Britain and on the European continent.

\section{Pennsylvania: A Tale of Two Statutes}

\subsection{Early-Nineteenth-Century Background}

Pennsylvania is a particularly good case for studying the effect of popular distrust of corporations and elite distrust of democracy on the availability and flexibility of business organizational forms. First, the expansion of the franchise occurred in Pennsylvania especially early. The state abolished property qualifications for voting even before the ratification of the Constitution, and Pennsylvania entered the new United States with a tax qualification that seems

\footnotetext{
${ }^{15}$ Hilt and O'Banion (2009) found "a surprising number" of limited partnerships in New York City in the early nineteenth century, counting 1,098 registrations between 1822 and 1858. However, Howard (1934) searched the records of five New Jersey counties from the 1830s until the 1930s and found only 140 registrations for limited partnerships. I compiled a sample of partnerships reported in the R. G. Dun credit ledgers for Boston for the 1840s and 1850 s and found that only 2 out of 164 were limited. For the details of the sample, see Lamoreaux (1997).
} 
to have been quite minimal. ${ }^{16}$ Second, controversy over the privileges that the legislature had granted to the Bank of North America, the financial arm of the national government under the Articles of Confederation, made corporations a hot-button political issue at the very time the franchise was expanding. Indeed, a populist-oriented legislature repealed the bank's Pennsylvania charter in 1785 , raising concerns about property rights in corporate stock. Although a political swing back toward the elite led to the reissuance of the charter two years later, the new version was less generous than the original, and the bank's supporters continued to feel under siege (Maier 1993, Hartz 1948, Hammond 1957, Schocket 2007). ${ }^{17}$

The reincarnated Bank of North America had a monopoly on banking in the state, and its leaders fought to maintain that position. They did not completely succeed; the legislature chartered three additional banks, all in Philadelphia, during the next couple of decades. These charters all went to supporters of the then dominant political coalition, known as the Federalists, and the banks' leaders joined together to lobby against additional applications for charters (Schwartz 1987, Majewski 2006, Schocket 2007). The vehemence with which the incumbents sought to block entry fueled suspicion that they were reaping exorbitant returns from their control of the credit market and insured that the issue of corporate privileges would remain a subject of heated public debate. As the political balance in the legislature shifted in the wake of the War of 1812, this anger about corporate privileges, coupled with the dire need for banking facilities in other parts of the state, spurred the passage in 1814 of an omnibus banking bill that chartered about two score new banks (Majewski 2006, Schocket 2007). Then the political

\footnotetext{
${ }^{16}$ Fully 71.5 percent of the state's adult white male population voted in the 1808 presidential election, and 77.4 percent voted in 1840. See Engerman and Sokoloff (2005).

${ }^{17}$ Farley Grubb (2003) has shown that prominent officers and shareholders in the Bank of North America sought to protect the bank's position as a monopoly issuer of currency in Pennsylvania by pushing successfully for the provision in the U.S. Constitution that banned paper money issues by the states. Paper money issues generally had broad popular support, but were regarded by the elite as a threat to property rights.
} 
balance shifted back again, and the movement for additional charters stalled. The relatively few banks incorporated over the next several decades had to pay hefty bonuses to the state in exchange for their charters, leading to charges of a corrupt bargain between banks and the legislature and raising the specter of more nefarious exchanges of money behind the scenes (Hartz 1948).

These charges provided the backdrop for Pennsylvania's constitutional convention of 1837, which opened in May, the same month as a massive financial panic forced all the banks in the state to suspend specie payments. The financial crisis dominated the convention's debates, focusing attention on banks almost to the exclusion of other types of corporations. Nonetheless, in their arguments over bank charters, delegates gave voice to all the same concerns that inflected discussions of corporations more generally — in particular, the fear that the unfair advantages that corporations obtained through their charters perpetuated the dominance of the moneyed elite. As one delegate put it, "the power now exercised by corporate bodies" was a threat to "equal rights." It must "be limited or abolished," and the only sure way to do that was increase the power of the people over their representations. Hence the delegates pushed to extend "the elective franchise ... as widely as possible" and, at the same time, subject all members of government, including judges, to election, so that "an immediate and direct action of the people may occur in the choice of those who are to administer that government" (Pennsylvania 1837, Vol. 1, 321-22). Defenders of corporations responded by raising the specter of insecure property rights. "Mark my words!" one delegate warned. "If ever our republic falls, it will be by the destruction of the confidence of our citizens in the security of individual rights," a consequence that "will necessarily follow" if democratically elected governments were allowed 
to countenance "the violation of contracts, the destruction of private rights, or the uprooting of charters" (Pennsylvania 1837, Vol. 5, 562-3).

The pro-democratic, anti-corporate forces made some gains at the convention, but only modest ones. They failed in their effort to eliminate tax qualifications for voting once and for all, though they did manage to secure a reduction in the residency requirement from two years to one-perhaps a more significant change, given and the highly mobile character of the population and the small magnitude of the tax qualification (Akagi 1924, Keyssar 2000, Pennsylvania 1837, Vol. 2, 470-96, 500-61, Vol. 3, 113-45, 148-73). They also failed in their demand that bank charters that perpetrated "a fraud upon the people" be considered "repealable" by the legislature (Pennsylvania 1837, Vol. 6, 434). Instead, all they obtained from the convention was a provision in the 1838 constitution limiting future bank charters to twenty years and requiring that each charter contain a clause "reserving to the legislature the power to alter, revoke, or annul the same, whenever in their opinion it may be injurious to the citizens of the commonwealth," a directive that was softened by the addition of language requiring that any such action be accomplished in "such manner ... that no injustice shall be done to the corporators" (Section $25) .^{18}$

From the perspective of hindsight, what is most striking about the debate over corporations that raged at the convention is how narrow it was. Delegates fought at great length over the issue of whether a corporate charter was a contract that future legislatures had to honor, even though this principle had presumably been already settled by the Supreme Court's

\footnotetext{
${ }^{18}$ The constitution was amended in 1857 to extend this clause to all corporations. The other major achievement of the convention was to bar the state from continuing to invest money in corporations. For the text of Pennsylvania's 1838 constitution and subsequent amendments, see the NBER/Maryland State Constitutions Project, http://www.stateconstitutions.umd.edu/index.aspx, accessed 8 June 2014.
} 
Dartmouth College decision. ${ }^{19}$ At the same time, there was surprisingly little discussion of the possibility of general incorporation. Delegates made a few attempts (all unsuccessful) to nudge the state toward a system of general laws (see, for examples, Pennsylvania 1837, Vol. 1, 129, Vol. 2, 172, and Vol. 6, 384), with proponents of general incorporation arguing that open access to the corporate form would counteract the inequality that the special charter system had exacerbated: "The principle of corporate or joint associations ... enabled the many, with small means, to compete with the few who were wealthy," and it would improve their position even more "if the monopoly principle of our present corporations were abolished, and all men left free to associate with shares, large or small, at their pleasure" (Pennsylvania 1837, Vol. 1, 385). Such proposals gained few adherents, however, probably because of the convention's focus on the banking crisis. Most delegates seem to have shared the view that allowing anyone who wanted to organize a bank would undermine the soundness of the financial system. Thus one delegate blamed the 1814 omnibus statute, which had granted charters to about 40 banks, for inflicting "on the commonwealth an evil of a more disastrous nature than has ever been experienced by its citizens" (Pennsylvania 1837, Vol. 5, 528). ${ }^{20}$

To this point, moreover, the delegates simply did not have much experience with general laws for business corporations. ${ }^{21}$ New York had enacted the first such statute for manufacturing in 1811 to encourage domestic production during the embargo on trade with Britain and France. $^{22}$ Only Ohio and New Jersey had followed suit, and both states later repealed their acts (Hilt 2013). Even in New York there was enough uncertainty about the principle of general

\footnotetext{
${ }^{19}$ Dartmouth College v. Woodward, 17 U.S. 518 (1819).

${ }^{20}$ The expansion of the number of banks in 1814 received much blame for the Panic of 1819. See Majewski (2006)

${ }^{21}$ Certainly, there was no aversion per se to the idea of general incorporation laws, for the Pennsylvania legislature had passed such laws for other purposes. As early as 1791, for example, it had enacted a statute enabling groups formed for "any literary, charitable, or for any religious purpose" to incorporate by a simple registration process (Pennsylvania 1810)

22 "AN ACT relative to Incorporations for Manufacturing Purposes," passed March 22, 1811. All acts cited by their titles are from the Session Laws of the respective state, available at www.heinonline.org.
} 
incorporation for business that the 1811 statute was initially enacted for only five years, though it was subsequently renewed before being made permanent in 1821 (Kessler 1940, and Seavoy 1982). At the time of the Pennsylvania convention, New York's pioneering free banking law was still a year in the future (Bodenhorn 2006). Some states, like Massachusetts and Rhode Island, had already loosened access to bank charters, but they had done so simply by regularizing the process of granting special charters, enabling the legislature to continue to deny applications to incorporators' whose character they thought suspect (Handlin and Handlin 1969, Lu and Wallis 2013, Lamoreaux 1994). Pennsylvania would not adopt a general incorporation statute for banking until 1860 (Hartz 1948).

Just the year before the constitutional convention, Pennsylvania's legislature had taken a first, very small, step in the direction of general incorporation by enacting a law that allowed companies that manufactured iron using processes fueled by coke or mineral coal to form corporations by a simple registration process. ${ }^{23}$ Not even other kinds of iron companies were allowed to avail themselves of the act. As Section 7 emphatically stated, "nothing herein contained, shall be construed to empower such corporation to manufacture iron which has not been manufactured from the ore, with coke or mineral coal," and the legislature only extended the act to companies manufacturing iron with charcoal in $1852 .{ }^{24}$ This first general incorporation law for manufacturing was highly restrictive in other ways as well. Charters for companies organized under the 1836 act were limited to twenty-five years duration. The companies had to have a capital of at least $\$ 100,000$ but not more than $\$ 500,000$, and they would forfeit their charters if at any time they contracted "debts to a greater amount than that of the capital subscribed." Companies could hold no more than 2,000 acres of land divided into no more than

\footnotetext{
23 “AN ACT To encourage the manufacture of Iron with Coke or Mineral Coal ...” 16 June 1836.

${ }^{24}$ It was extended to companies that made steel as well as iron in 1864. See Eastman 1908, Vol. 1, p. 6.
} 
three parcels, all of which had to be in the same county or in "two counties which shall adjoin each other" (Sections 1, 3 and 6). Furthermore, companies were to be managed by a board of directors elected by the stockholders according to a proportional voting rule that limited the number of votes large shareholders could cast (Section 3).

The legislature continued in this prescriptive spirit when it enacted a law "To encourage manufacturing operations in this commonwealth" in 1849. Despite the opening words of the bill, the act initially applied only to a limited set of companies formed "for the purpose of carrying on the manufacture of woolen, cotton flax, or silk goods, or of iron, paper, lumber or salt," ${ }^{, 5}$ though coverage was gradually extended over the next couple of decades to "the manufacture of glass" (1850), "articles made from salt, except in Philadelphia" (1851), "printing and publishing" (1851), the "manufacture of enamelled and vitrified iron, and articles made of cast or wrought iron, coated with glass or enamel, within the County of Allegheny" (1852), "oil and other products of rosin" (1852), "mining and manufacturing of mineral paints and artificial slates and other articles made by the use of said painting materials except in Philadelphia" (1852), "manufacture of artificial manures, and of articles made out of iron and other metals, or out of wood, iron and other metals" (1853), "mining coal, mining, quarrying and preparing for market lime, marl, soda, hydraulic cement, or other minerals, smelting copper, lead, tin or zinc ores, quarrying marble, stone or slate, and manufacturing lumber" (1853), "manufacture of flour in Philadelphia and Beaver counties" (1853), “quarrying, preparing for market and vending marble, sandstone and other stone used for building purposes" (1853), "common carriers, without the capacity to hold real estate" (1854), "manufacture of leather in certain counties" (1859), "manufacture of oils, hydro-carbon fluids and all other products resulting from subjecting coal of any kind to the action of heat or the process of distillation" (1859), "manufacture of oil from

\footnotetext{
25 "AN ACT To encourage manufacturing operations in this commonwealth," 7 April 1849.
} 
mineral coal in Beaver County" (1859), "the mining, manufacturing and refining of carbon oil" (1860), “manufacture of fuel” (1860), “manufacture and preparation of lubricating oil and material, out of and from mineral oils, and other oils or fatty substances, whether mineral animal or vegetable" (1863), and the "manufacture of leather in the county of Elk" (1865) (Eastman 1908, Vol. 1, 8-9).

Like the original 1836 law, the 1849 act and its supplements imposed substantial restrictions on the activities and internal governance structures of companies chartered under their auspices. Although companies faced no ceilings on capital and could incur liabilities up to three times the amount of their paid-in stock, they could not hold more than 2,000 acres in real estate and their duration was limited to twenty years. They were to be managed by a board of 5 to 13 directors, the majority of whom had to be citizens of the United States. The president had to be a director, but the secretary and treasurer could not be. Stockholders had one vote per share, but no individual stockholder could cast votes amounting to more than one-third of the issued shares. Directors had the power to make bylaws "subject however to the revision and approval of the stockholders." Elaborate rules governed voting by proxy (for example, "no stockholder, females excepted, residing within ten miles of the place appointed for such general meeting or election, shall vote by proxy"), the powers of directors (they could not use the company's funds “for any banking purposes whatever, nor in the purchase of any stock in any other corporation," nor to make loans to any stockholder or officer on the security of the company's own stock), the calling special meetings, and procedures for increasing or decreasing the company's capital. ${ }^{26}$

Because Pennsylvania's general incorporation laws were so restrictive, companies continued to petition for special charters from the legislature in the hopes of securing better

26 “AN ACT To encourage manufacturing operations in this commonwealth,” 7 April 1849. 
terms. Five years after the passage of the 1849 law, less than a dozen companies had incorporated under it (Hartz 1948). Yet in 1855 alone the legislature passed 196 private bills chartering or amending the charters of for-profit business corporations (Pennsylvania 1855). A significant proportion of these bills pertained, of course, to types of enterprises that could not incorporate under the general laws, but many companies that could incorporate by registration still sought special charters in order to escape some of the restrictive features of the general laws. For example, in the iron industry one can observe companies obtaining special charters in order to buy stock in other companies, engage in related lines of business (such as building a railroad or a telegraph), borrow money in greater amounts than allowed by the general statute, institute non-standard voting rules for elections for directors, and even occasionally escape the limits on real estate holdings. ${ }^{27}$

Incorporators resented having to lobby the legislature to secure provisions they regarded as reasonable or to be able to incorporate in the first place if their industries were not covered by general laws. Moreover, in some politically sensitive industries, charters were difficult to get under any circumstances. In coal mining, for example, the legislature adopted a policy of chartering corporations only in areas where the industry was not yet established, and so it refused almost all requests for charters in anthracite-rich areas such as Schuylkill County (Adams 2006). In other sectors, like banking, charters were simply expensive to obtain (Hartz 1948), and those seeking to form corporations had to hire agents, variously known as "middle housemen," "lobby members," or more graphically "borers," to advance their cause (Pennsylvania 1837, Vol. 6, 92).

\footnotetext{
${ }^{27}$ See, for examples, "AN ACT To enable the Sharon Iron Company, of Mercer county, to subscribe to the Stock of the Pittsburg and Erie Railroad Company," 5 April 1855; "AN ACT to incorporate the Hopewell Coal and Iron Company," 7 May 1855; "AN ACT To incorporate the Saucona Iron Company, in the county of Northampton," 8 April 1857; "AN ACT To incorporate the Sullivan Coal and Iron Company," 2 March 1868; “AN ACT To incorporate the Emaus Iron Company," 11 March 1870; "AN ACT Relative to the Bloomsburg Iron Company, 12 March 1870; "A Further Supplement To an act, entitled 'An Act to incorporate the Emaus Iron Company ..." 2 April 1872. The evidence in many of the charters and supplements is contrary to Hamill's claim (1999) that special charters were generally little different in their salient features than charters obtained under general laws.
} 
The activities of these lobbyists fueled complaints about corruption and increased antipathy both to corporations and the legislature. It was almost impossible, critics charged, to get a bill through the assembly "without the aid and influence of that class of men called 'borers,' whose business it is to flatter, cajole, treat, and, perhaps, bribe the members ... These are the men who procure charters for banks, rail roads, \&c., and, who offer for every vote they get, a consideration in some form or other" (Pennsylvania 1837, Vol. 6, 434). The sight of legislators "beset by borers," wielding not "the power of the sword, but, what is a thousand times more mischievous, the power of the purse" (Pennsylvania 1837, Vol. 6, 183) reinforced in the public's mind the idea that corporate power was illegitimate and had to be restrained for the survival of the Republic. As one delegate to the 1837 convention put it, there was a critical need for constitutional restrictions on banking "to guard our legislature from the importunities of such men" (Pennsylvania 1837, Vol. 6, 92). When that effort bore little fruit, the conviction grew that it was necessary to tie the hands of legislators so far as the chartering of corporations was concerned.

\subsection{The 1872-73 Constitutional Convention}

The passage by Congress of the National Banking Acts during the Civil War took the issue of bank charters off the table for at least the next couple of decades. These statutes instituted a general incorporation system for banks at the federal level and, by taxing the notes of state chartered banks, made it unattractive for banks to seek state charters. ${ }^{28}$ Nonetheless, veterans returned from the fighting to find Pennsylvania's economy seemingly transformed by the large number of corporations the legislature had chartered during the war. In Schuylkill

\footnotetext{
${ }^{28}$ This situation would change during the 1880 s, when deposits grew relative to currency issues on banks' balance sheets, but at least through the 1870 s relatively few banks sought state charters. Pennsylvania had enacted a general incorporation law for banking in 1860 (Hartz 1948), but the law was scarcely operational before the National Banking Acts stripped it of any significance.
} 
County, for example, the number of coal-mining corporations had increased from 1 to 52, and corporations suddenly accounted for about half of the county's output (Adams 2006 and 2012). Although Pennsylvania loosened its general incorporation law during the Civil War, nearly 40 percent of the new coal-mining corporations in the state had obtained special charters from the legislature and almost an equivalent number of companies secured charter supplements that expanded their privileges. Not surprisingly, critics raised questions about the legislative bargains that allowed these "soulless monsters" suddenly to play such a prominent role in the state's economy (Adams 2012).

The issue came to a head in 1872 when it came time for Pennsylvania again to rewrite its fundamental law. As the delegates gathered in November of that year to draft a new state constitution, it quickly became apparent that the central reform impulse of the convention would be to get the legislature out of the business of passing "local or special" laws of all types. First and foremost among the types of legislation the delegates singled out for prohibition were special charters of incorporation. But if businesses were no longer going to be able to secure special charters that met their needs, then the restrictive character of the state's general incorporation laws posed serious problems. How would companies in industries not covered by the general laws obtain charters? Would all companies now have to conform to the restrictive features of these laws?

Worried industrialists found a champion at the convention in the person of Henry C. Carey, the well-known writer on political economy. Carey, a Republican delegate at large, ${ }^{29}$ chaired the Committee on Industrial Interests and Labor, and he embedded his views in the committee report he presented to the convention (Pennsylvania 1873, Vol. 5, 470-81). The new constitution, he proclaimed, should guarantee " $[\mathrm{t}]$ he right of the people of the State to associate

\footnotetext{
${ }^{29}$ Information on the political affiliations of the delegates and the districts they represented is from Harlan (1873).
} 
together for all lawful purposes, and for trading on principles of limited or unlimited liability" (Pennsylvania 1873, Vol. 5, 481). In other words, it should embody the principle that Douglass North, John Wallis, and Barry Weingast (2009) have called "open access," where the government no longer determines who can form such organizations or what the organizations can do.

Carey complained that in Pennsylvania, in contrast to Great Britain and a few of the other U.S. states, "the right of association, for any purposes of trade or profit, has never been admitted" (Pennsylvania 1873, Vol. 5, 479). He offered as an example a so-called general incorporation law enacted by the legislature the previous year. The statute applied only to iron and steel and other enumerated types of manufacturing enterprises, but more importantly, it imposed significant disadvantages on enterprises that chose to limit their liabilities. Limited enterprises had to pay a higher "bonus" to the state at the time of their formation. In addition, their shareholders remained unlimitedly liable "for debts due for labor or services" (Pennsylvania 1873, Vol. 5, 480). Because Pennsylvania's general laws routinely imposed such taxes and liabilities on members of corporations that formed under them, Carey pointed out, they have “remained almost, if not absolutely, a dead letter" (Pennsylvania 1873, Vol. 5, 480). Businesses could only get reasonable terms by seeking instead to incorporate under special acts, but now that alternative was going to be foreclosed.

Carey's committee did not have jurisdiction over the parts of the constitution that concerned corporations, so it overstepped its authority in proposing that the new constitution include a right to associate. The committee that had jurisdiction, the "Committee on Private Corporations," did not include any similar principle in the article it initially drafted. However, on the article's second reading, the committee's chair, George W. Woodward (Chief Justice of 
the Pennsylvania Supreme Court and a Democratic delegate at large), proposed an amendment that Carey accepted as a close substitute:

It shall be the duty of the Legislature to provide by general enactment that any five or more persons, citizens of this Commonwealth, associated for the prosecution of any lawful business, may, by subscribing to articles of association and complying with all requirements of law, form themselves into an incorporated company, with or without limited liability, as may be expressed in the articles of association, and such publicity shall be provided for as shall enable all who trade with such corporations as adopt the limited liability to know that no liability exists beyond that of the joint capital which may have been subscribed." (Pennsylvania 1873, Vol. 6, 17)

After an extensive discussion, the convention agreed provisionally to a revised version of the amendment that cut the phrase about the legislature's duty and simply conferred the right of association on "any two or more persons, citizens of this Commonwealth" (Pennsylvania 1873, Vol. 6, 27).

This amendment, however, was stricken from the draft article on its third reading. Despite Woodward's support, the amendment had been added mainly with Republican votes. Republicans had overwhelmingly supported the measure on second reading, with 40 in favor and only 11 opposed, whereas the Democratic delegates had been evenly divided, with 23 for and 25 against (Pennsylvania 1873, Vol. 6, 27). ${ }^{30}$ After the debate heated up on the third reading, Democrats voted to strike the amendment by a three to one margin, 33 to 11 . The Republican

\footnotetext{
${ }^{30}$ One Liberal Republican and two unaffiliated at-large delegates also voted for the amendment. Thirteen Democrats, seventeen Republicans, and 1 unaffiliated at-large delegate were absent at the time of the vote.
} 
vote was closer, but Republicans also favored striking the amendment by a vote of 27 to 23 (Pennsylvania 1873, Vol. 7, 779). ${ }^{31}$

If Republican delegates had continued to support the proposition in the original proportions, the amendment would have passed, but Democratic opponents of corporations shrewdly and successfully played on Republican fears about the security of property rights. When the amendment had been originally proposed, a few Democratic delegates had spoken against it on the grounds that it was "class legislation in favor of capitalists" (Pennsylvania 1873, Vol. 6, 23). On the third reading, however, these opponents moved beyond their general antipathy to corporations to expound on the dangers to creditors of making limited liability so broadly accessible to small firms. Thus S. C. T. Dodd warned that "we shall have no more partnerships; individuals cannot do business; it will be all done by corporations ... and every one knows that the moment men form themselves into a corporation they lose their moral responsibility in their business" (Pennsylvania 1873, Vol. 7, 765). ${ }^{32}$ Such expressions of concern for creditors of small businesses were somewhat disingenuous. As the convention's subsequent actions make clear, the positions of many of the Democratic representatives were driven by fears about the economic power of large-scale business and the wealthy individuals who dominated them. Their warnings about the dangers of limited liability resonated, however, with a certain type of Republican worried about protecting creditors' rights. As one Republican delegate who had originally supported the amendment fretted, the clause would enable any two persons to "set up a grocery on the corner in any town, advertise that they have put in a thousand dollars, spend it all, and leave their creditors minus" (Pennsylvania 1873, Vol. 7, 763). As a consequence, the

\footnotetext{
${ }^{31}$ One Liberal Republican voted to delete the amendment and three unaffiliated at-large delegates voted to keep it. Seventeen Democrats and eighteen Republicans were absent at the time of the vote.

${ }^{32}$ Ironically, about a decade later, Dodd would, as lawyer for Standard Oil, engineer the formation of the Standard Oil Trust.
} 
vote on striking the amendment was much less split along party lines than other votes on corporations.

Not only did Democrats in the convention oppose embodying in the constitution a right freely to form corporations, but they went further and imbedded in that document rules that restricted what corporations could do and how they could be governed (Pennsylvania 1874a). These rules were of a specificity that one normally might expect to be reserved for statutes. Their presence in the state's fundamental law signaled the delegates' continued commitment to the idea that the corporate form facilitated a dangerous concentration of economic power that had to be controlled. Hence the 1873 Constitution specified such details as a corporation could not hold real estate beyond what was "necessary and proper for its legitimate business" (Article XVI, Section 6), "no corporation shall issue stocks or bonds except for money, labor done, or money or property actually received" (Article XVI, Section 7), and increases in capital within the ceilings allowed by law required "the consent of the persons holding the larger amount in value of the stock" obtained at a meeting "held after sixty days notice" (Article XVI, Section 7). The constitution even imposed a uniform voting rule for "all elections for directors or managers of a corporation" in order to give minority shareholders a better change to secure representation on the board. It mandated that "each member or shareholder may cast the whole number of his votes for one candidate, or distribute them upon two or more candidates, as he may prefer" (in other words, the constitution required what is known as cumulative voting) (Article XVI, Section 4).

The most vocal supporters of including these restrictions in the constitution spoke about the evils of corporate privileges and corrupting influence that corporate lobbyists had on the legislature. Thus Charles R. Buckalew, a Democratic delegate from a largely rural part of the 
state, countered an objection that the requirement that corporations adopt cumulative voting bypassed the legislature and stripped it of its authority to set corporate governance rules by claiming that legislators had been so corrupted by large corporations that they could not be trusted to use their powers for the public good:

Yes, sir, it does take away the power from the Legislature to give undue power to dominating men or cliques who undertake to run corporations in their own special interests and to the disadvantage of the stockholders. It is a check upon the Fisks and the Vanderbilts of the country in manipulating Legislatures to the injury of the general stockholders of a company; and that is all the effect that it has. The Legislature ought not to have this subject in charge. It ought to be settled as one of the fundamental arrangements concerning these corporate bodies. (Pennsylvania 1873, Vol. 5, 759) Rallying to this kind of traditional anti-corporate rhetoric, Democratic delegates voted overwhelmingly ( 37 to 7 ) in favor of inserting into the constitution the requirement that corporations adopt cumulative voting. A large majority of Republican delegates opposed the measure (the Republican vote was 14 to 27), but that was not enough to prevent its passage on second reading (Pennsylvania 1873, Vol. 5, 768), ${ }^{33}$ and the provision easily withstood a motion to delete it on the third reading of the bill (Pennsylvania 1873, Vol. 7, 760-61).

Pennsylvania's 1873 Constitution stripped the legislature of much more than the right to regulate voting procedures in corporations (see Pennsylvania 1874a). The revulsion that Delegate Buckalew expressed about the corrupt use of legislative power permeated the entire convention. As a result, Article III, Section 7 contained a long list of categories of special legislation that the legislature was henceforward prohibited from enacting, ranging from the

\footnotetext{
${ }^{33}$ The one Liberal Republican voted for cumulative voting, and two unaffiliated at-large delegates voted against. One unaffiliated at-large delegate was absent at the time of the vote, as were 17 Democrats and 27 Republicans.
} 
political (laws "locating or changing county seats, erecting new counties or changing county lines," "creating offices, or prescribing the powers and duties of officers in counties, cities, boroughs, townships, election or school districts," "for the opening and conducting of elections, or fixing or changing the place of voting") to the judicial (laws "changing the venue in civil or criminal cases" or "regulating the practice or jurisdiction of, or changing the rules of evidence in, any judicial proceeding") to the personal (laws "changing the names of persons or places," "authorizing the adoption or legitimation of children," or "granting divorces"). Prominent on the list, however, was the prohibition against special charters of incorporation: "The General Assembly shall not pass any local or special law ... Creating corporations, or amending, renewing or extending the charters thereof [or] Granting to any corporation, association or individual any special or exclusive privilege or immunity ..."34 No longer would the legislature have the power to enact private bills that enabled corporations to evade the restrictive provisions of the general laws.

\subsection{Pennsylvania's 1874 General Incorporation Law}

Now that there was no escape hatch through private legislation, the content of the public laws governing corporations became critically important. When the new legislature convened in early 1874 , the senate immediately got to work on a revision of the state's general incorporation law. The senators who tackled the assignment understood the stakes involved. As one member put it, "While we agree that the prohibition against special legislation creating corporations is wise, we also agree that we must be careful of the ground upon which we are walking." He went on to warn against writing a statue that will "build up a Chinese wall around our great State" that

\footnotetext{
${ }^{34}$ Many other states enacted similar constitutional prohibitions around the same time. See Hennessey and Wallis 2014.
} 
will scare off foreign capital (Pennsylvania 1874b, 541). The Speaker of the Senate, Butler B. Strang (a Republican from Tioga County) put the matter even more bluntly. Referring to the undeveloped parts of the state, he proclaimed, "[I]n my judgment, the question [is] whether that provision of the new Constitution ... is to operate so as to entirely blot out the enterprise and the investment of capital" (Pennsylvania 1874b, 541).

Although Republicans dominated both houses of the Pennsylvania legislature in 1874, the statute that finally passed on April 29, 1874 fell dramatically short of what Carey and his allies in the constitutional convention had wanted. ${ }^{35}$ Rather than a liberal statement of the right of association, the statute restricted access to corporate charters to a list of specifically enumerated types of enterprises. ${ }^{36}$ Rather than simply granting members of corporations limited liability, it continued to burden them with additional liabilities. Rather than a statute that allowed incorporators a great deal of contractual flexibility like the British law Carey so admired, the act mandated important aspects of every corporation's governance structure. In addition, the law placed strict limitations on the size of many types of corporations, as well as the extent of their real estate holdings and indebtedness.

More specifically, the statute directed that the business of any manufacturing, mining or quarrying company must "be confined exclusively to the purpose ... specified in its charter, and no such company shall manufacture or sell any commodity or articles of merchandise other than

\footnotetext{
${ }^{35}$ See "AN ACT To provide for the incorporation and regulation of certain corporations," enacted 29 April 1874.

${ }^{36}$ "Section 2 listed the types of "Corporations Not for Profit" that could be formed under the act and also the types of "Corporations for Profit." The latter included narrow categories, such as "the supply of ice to the public," or "the construction and maintenance of a bridge over streams within this state," but also broad categories, such as "the carrying on of any mechanical, mining, quarrying or manufacturing business." "The manufacture of iron or steel" was listed separately from other manufacturing activities, and the statute imposed some different rules on corporations in this category, as it did for other specific types of corporations.
} 
those therein specified" (section 43). ${ }^{37}$ Shareholders were subject to double liability. That is, in addition to their investment, they were individually liable "to the amount of stock held by each of them, for all work or labor done, or materials furnished, to carry on the operations" of their company (Section 14). Shareholders in iron and steel companies were fully liable as individuals for "debts due to the laborers, mechanics, or clerks, for services" provided in the past six months (Section 38, Clause 8). Those in manufacturing companies more generally were jointly and severally liable for the company's debts "[i]f any part of the capital stock ... [was] withdrawn and refunded to the stockholders." Directors were also personally liable for dividends declared when the company was insolvent or if they encumbered the enterprise beyond the statutory ceiling (Section 39, Clause 5).

Corporations could enact bylaws for their governance, but the statute specified that the business of every corporation "shall be managed and conducted by a president, a board of directors or trustees, a clerk, a treasurer," and such other officers as the corporation authorizes. Directors or trustees were to be chosen annually by the stockholders. There must be at least three, and a majority had to be present for the board to act (Section 5). As mandated by the state constitution, stockholders had the right to cumulate their votes for specific directors or trustees (Section 10). Corporations could borrow money but, except as otherwise provided by the act, only to an amount "not exceeding one-half of the capital stock ... paid in, and at a rate of interest not exceeding six per centum" (Section 13). Corporations could issue preferred stock with the "consent of a majority in interest of its stockholders, obtained at a meeting to be called for that purpose" (Section 16). The law required a similar majority vote of the stockholders to increase

\footnotetext{
${ }^{37}$ Legislators were especially concerned to prevent corporations from establishing company stores, and the section went on to restrict buying and selling on company premises and to prohibit companies from withholding employees' wages in payment for goods. Seen for examples, Pennsylvania (1874b), 1019, 1134, 1145.
} 
or decrease a corporation's capital and specified in elaborate detail the method of conducting such a ballot (Sections 19-21).

With a few exceptions, corporations chartered under the act were limited to $\$ 1$ million in capital (Section 11). Iron and steel companies could have a capital of up to $\$ 5$ million and could issue bonds amounting to three times paid-in capital ("bearing interest not exceeding six per centum"), but they could not hold more than 10,000 acres of land within the state, "including leased lands" (Section 38, Clause 1). As a general rule, it was not lawful for corporations to use their funds to purchase stock in any other corporation "or to hold the same, except as collateral security for a prior indebtedness" (Section 11), but iron and steel companies were specifically exempted from this prohibition (Section 38, Clause 6). "Companies incorporated ... for the carrying on of any mechanical, mining, quarrying, or manufacturing” business also faced a ceiling on capital of $\$ 5$ million dollars, but these companies, upon the vote of three quarters of their stockholders, could also issue a second kind of stock called "special stock" up to two-fifths of their total capital. Special stock resembled bonds in that it was "subject to redemption at par, after a fixed time, to be stated in the certificates." It also bore a fixed rate of dividend, "not exceeding four percentum." Holders of special stock bore no personal liability beyond their investment. Mechanical, mining, quarrying, and manufacturing corporations could hold real estate, but only so much as was "necessary for the purpose of its organization," and they could borrow up to the amount of their paid-in capital (Section 39, clause 7).

The prescriptive features of the bill were present when it was first reported out of committee (as Senate Bill No. 44) on February 11, 1874, and they survived the amendment process largely intact. Most of them did not even generate any discussion. The main exception was a provision limiting the amount of land that iron and steel companies could own or lease to 
10,000 acres. Thomas Chalfant, a Democratic senator who represented Columbia, Montour,

Lycoming, and Sullivan counties, proposed an amendment that would reduce the figure to 5,000

acres, and his motion generated a heated exchange about the need to attract capital to develop the state's resources versus the danger of allowing corporations to monopolize those resources.

Chalfant's motion was defeated by a vote of 15 to 10 (eleven Republicans and one Liberal Republican voted against the amendment and six Republicans voted in favor of it). ${ }^{38}$ What is most striking, however, is that no one in this Republican-dominated senate argued that the limitation on land holdings should be removed altogether. Rather the debate was over whether the provision should be even stricter than the one in the original draft.

\subsection{Pennsylvania's 1874 Statute for Partnership Associations}

The Republicans, it seems, had something else up their sleeves, for a few days after the legislature passed the new general incorporation law, the senate began consideration of an enabling statute for another form of limited liability company that would not be called a corporation and hence would not push any of the same political buttons. ${ }^{39}$ Senate Bill No. 295 , "An act authorizing the formation of partnership associations ..." was introduced in the legislature on May 4 and became law on June $2 .{ }^{40}$ The statute passed with overwhelming bipartisan support and generated little debate in either house en route to passage. ${ }^{41}$

\footnotetext{
${ }^{38}$ Three Republicans were absent. The Democrat vote was 4 in favor, 3 opposed, and 5 absent. For the vote, see Pennsylvania (1874b), 542. The party affiliations of the senators are from Smull (1874).

${ }^{39}$ As Edward H. Warren later cynically commented, "it would seem to be probably that those who favored the principle of liability limited to the capital subscribed thought that the legislature would be more likely to pass a law sanctioning such a limitation if the term 'corporations' were avoided in framing the law." See Warren (1929), 512. ${ }^{40}$ As will become clear, the new form was much like a modern LLC. See "AN ACT Authoring the formation of partnership associations, in which the capital subscribed shall alone be responsible for the debts of the association, except under certain circumstances" 2 June 1874.

${ }^{41}$ In the senate, Republicans voted 14 to 1 in favor ( 5 absent) and Democrats, 6 to 2 in favor ( 4 absent. In the House, Republicans voted 74 to 2 in support of the bill ( 8 absent), and Democrats, 23 to 13 ( 7 absent). For the roll call votes, see Pennsylvania (1874b), 1982. Party affiliations are from Smull (1874).
} 
In many respects the bill was opposite in spirit to the general incorporation act. It was only three pages long, as opposed to thirty-five pages for the corporation bill, and the business form it enabled was remarkably flexible. The bill's simple language allowing "any three or more persons ... to form a partnership association, for the purpose of conducting any lawful business or occupation within the United States or elsewhere" was similar to Carey's original proposal to the constitutional convention. Although the term of a partnership association was limited to a maximum of twenty years, there were no ceilings on capital or on the amount of real estate that could be owned and no restrictions on the types of business in which the firm could engage, the state of citizenship of the incorporators, or where the company could conduct its business (so long as it maintained a headquarters in Pennsylvania). Any three people could form a partnership association simply by registering with a local county official. A supplementary act passed on May 1, 1876 allowed the capital to be paid in "in real or personal estate, mines or other property, at a valuation to be approved by all the members subscribing .....,42

The main difference between the bill and Carey's proposal was a provision that linked the new form to the ordinary partnership by enabling the existing membership to determine whether or not to admit new members. Section 4 of the act provided that interests in a partnership association, like those in a corporation, were to be considered "personal estate" and hence transferrable, but it also specified that "no transferee of any interest ... shall be entitled thereafter to any participation in the subsequent business of said association, unless he or she be elected thereto by a vote of a majority of the members in number and value of their interests ...." The statute thus explicitly allowed (indeed, required) members of partnership associations to do something that members of corporations could not easily do at this time - control the identity of

\footnotetext{
42 “AN ACT Supplementary to the act, approved the second day of June, Anno Domini eighteen hundred and seventy-four, ... providing for the contribution of real and personal estate to the capital stock ..." 1 May 1876.
} 
their associates. ${ }^{43}$ In Pennsylvania, as elsewhere in the late nineteenth century, courts did not permit corporations to enact by-laws that impeded the transferability of shares. They generally refused to uphold rules that limited in any way shareholders' ability to sell their property, including those that required shareholders to give each other a first right of refusal. ${ }^{44}$

In other respects, the enabling act for partnership associations was highly permissive with respect to internal governance. The act specified procedures for winding up the company, required partnership associations to hold at least one general meeting each year at which the membership would elect three to five managers, including a chairman, a secretary, and a treasurer (or a chairman and a secretary-treasurer) (Section 5), and forbid a partnership association from lending "its credit, its name or its capital" to any of its members (or to anyone else without "the consent in writing of a majority in number and value of interest") (Section 7). Otherwise, all governance rules were up to the members. ${ }^{45}$

The limit on the transferability of shares should have made it more difficult for partnership associations to raise capital from external investors and thus may have been what made the form palatable to Democrats fearful of concentrations of capital. Intriguingly, however, the greater flexibility of the form seems to have heightened its appeal to some very large enterprises. Although there are no general counts of the numbers and types of firms that adopted the form, I collected the registrations of all partnership associations filed in the county of

\footnotetext{
${ }^{43}$ However, a supplementary statute enacted on 25 June 1885 enabled organizers of a partnership association to opt out of this provision. See "A SUPPLEMENT To an act, entitled "An act authorizing the formation of partnership associations,...' regulating the transfer of interests in said partnerships associations."

${ }^{44}$ For Pennsylvania cases recognizing that the transfer rules for partnership associations was different than for corporations, see Eliot v. Himrod, 108 Pa. 569 (1885); and Carter v. Producers' Oil Co., Ltd., 182 Pa. 551 (1897). A Maryland Court of Appeals articulated the general principle in 1896, when it ruled that any such bylaws constituted "an unreasonable and a palpable restraint upon the alienation of property." See Bloede Co. v. Bloede, 84 Md. 129 (1896) at 141. For further discussion and additional case citations, see Harris and Lamoreaux (2010).

${ }^{45}$ About two decades later, the legislature imposed a voting rule of a "majority in value of interest" for the choice of managers and a "majority in number and value of interest" to adopt bylaws. By then, however, the popularity of the form had peaked. See "A SUPPLEMENT To an act, entitled 'an act to authorize the formation of partnership associations, ... providing for the continuance of such associations after the expiration of the original term, prescribing the manner of electing managers thereof ...” 8 June 1895.
} 
Philadelphia for every fifth year beginning in $1877 .{ }^{46}$ As Table 2 shows, most of the firms adopting the new form were small, but especially early on a significant number of larger enterprises found the partnership-association form appealing. As late as 1887, approximately a fifth of the registrants had capitalizations of $\$ 100,000$ or more, and several had considerably more. $^{47}$

An important example of a large partnership association (though not one registered in Philadelphia) was the Carnegie Steel Company, Limited, capitalized at \$25 million. At the time of its organization in 1892, the company included four major steel plants, several iron furnaces and mills, two coke works, and an assortment of other properties. The form appealed to the owners because of Andrew Carnegie's dominant position in the company. A few years earlier Carnegie had been so seriously ill that it appeared he would die, and his partners in the company's predecessor firms (all ordinary partnerships) had faced the dire prospect that the companies would be bankrupted by the cost of settling Carnegie's estate. Although they could have protected themselves by organizing their enterprise as a corporation, Carnegie was not willing to go along. He wanted to be able to control who could be a member of the firm, reward talented managers with ownership shares, and rid the firm of partners who did not share his strategic vision. The solution, the so-called "Iron Clad" agreement, was possible under the flexible partnership association statute but not under the Pennsylvania's general incorporation law. In the event of Carnegie's death, his partners got the right to buy out his interest at book value over an extended period of time (fifteen years). In exchange, Carnegie got a clause that

\footnotetext{
${ }^{46}$ Partnership Books, 1836-1955, RG 5.23, City Archives, City of Philadelphia, Department of Records. There are tax ledgers in the state archives beginning in 1880 that include partnership associations, but I could not find in them many of the partnership associations that I know existed. See State Treasurer, Capital Stock Tax Ledgers, 18761900. These records were indexed in two volumes mislabeled as Corporate Endorsement Index, Nos. 7-8, 1909-13. For later years, see Bonus Ledgers for Limited Partnerships and Associations, No. 1, 1914-16. These volumes are all in Record Group 28, Records of Treasury Department, Pennsylvania State Archives, Harrisburg, Pennsylvania. ${ }^{47}$ Partnership associations initially had more advantageous tax treatment than corporations, but the legislature eliminated that difference in 1879 (Freedley 1883).
} 
enabled him (upon the vote of three-quarters of the members in number and value of shares) to force a partner to sell out his interest in the company at book value. ${ }^{48}$

Another example of an important firm that took the partnership association form was the Bessemer Steel Company, Limited, the patent pool that controlled the process of making Bessemer steel in the United States. This company filed its registration papers in Philadelphia in 1877. It had an initial capital of $\$ 825,000$ and a membership consisting of five individuals (the association's managers) and eleven major steel companies. The firms that belonged to the association had the right to use patents held by the pool at the cost of a specified royalty per ton of steel produced. Profits from the royalties were then divided among the members in the form of dividends. The partnership-association form allowed members of the pool to develop a set of enforceable rules to control access to steel technology. Members that did not adhere to the rules, that failed to give a proper accounting of their production, or that refused to pay royalties they owed could be expelled by a two-thirds vote of the "members present at a meeting called for the purpose ... and shall thereafter have no rights in the Association or in the property which it owns and controls." $" 49$

The ability to control access to valuable property also explains the attractiveness of the form for the Producers' Oil Company, a partnership association created by an organization of oil producers (the Producers' Protective Association) with the aim of liberating well owners from their dependence on the Standard Oil Trust. The whole purpose of the enterprise was to gain control of oil supplies and keep them out of Standard's hands. If the company had been

\footnotetext{
${ }^{48}$ The threat of Carnegie's death gave all the partners an interest in keeping the company's book value below market value, so the agreement had considerable bite. The details of the agreement became public when Carnegie tried to force Henry Clay Frick out, and Frick sued to get the company revalued. See Wall (1970), 491-93; Livesay (1975), 171-72; and Bridge (1903), 336-38.

${ }^{49}$ Articles of Association of the Bessemer Steel Company, Limited, 1 March 1877, in Limited Partnerships, F. T. W., 1873-1879 (LP4), Partnership Books, 1836-1955, RG 5.23, City Archives, City of Philadelphia, Department of Records.
} 
organized as a corporation, the producers would never have been able to prevent some of their number from selling out to Standard; they had suffered such defections before. The partnershipassociation form gave them the necessary means, however, because the simple purchase of shares was not sufficient to convey membership in the company (Tarbell 1904, Vol. 2, Ch. 15). Transferees had also to be voted in by the continuing membership. In fact, parties associated with Standard managed to buy up a huge block of the shares in the Producers' Oil Company, but they were not admitted to the company. John J. Carter, the member of the company who took possession of these shares on behalf of the Standard interests, sued to be allowed to vote the additional interest, but he was not successful. On appeal, the Supreme Court of Pennsylvania ruled in favor of the partnership association. "We cannot assent," the justices declared, "to the plaintiff's claim that the defendant company is a corporation restricted, in the adoption of bylaws, rules and regulations for its government, to such as it is within the power of the latter to prescribe. It may be conceded that the defendant company has some of the qualities of a corporation, but it is nevertheless a partnership association, governed by the statutes and articles under which it was organized." ${ }^{, 50}$ Under Pennsylvania law corporations had to adhere to governance rules imposed by the statute and could not restrict the transferability or voting rights of shares. But partnership associations had much more contractual flexibility, and by means of carefully worded bylaws the Producers' Oil Company was able to prevent Standard Oil from buying control. ${ }^{51}$

\footnotetext{
${ }^{50}$ Carter v. Producers' Oil Co., Ltd., 182 Pa. 551 (1897) at 573-74.

${ }^{51}$ The company had adopted a bylaw prohibiting any member from selling or transferring "any interest in capital or shares of stock to any person not a member in good standing of the Producers' Protective Association, unless with the approval in writing of a majority of the board of managers." The bylaw also specified that "[n]o transferee of any interest in capital or shares of stock shall be entitled to participate in the subsequent business or profits of the association, or to vote on such interest or shares so transferred, unless elected to membership therein by a vote of a majority of the members in number and value of their interests." Carter v. Producers' Oil Co., Ltd., $182 \mathrm{~Pa} .551$ (1897), "Prior History."
} 
The courts' willingness to treat partnership associations differently from corporations could also be a disadvantage, however. In an 1885 debt case involving the Keystone Boot and Shoe Company, Limited, the Pennsylvania Supreme Court used this same feature of partnership associations to justify piercing the veil of limited liability and holding the members unlimitedly liable as general partners. Although for convenience partnership associations were "clothed with many of the features and powers of a corporation," the court ruled that in a partnership association, unlike a corporation, "no man can purchase the interest of a member and participate in the subsequent business, unless by a vote of a majority of the members in number and value of their interests." Partnership associations were thus in a fundamental way different from corporations. Moreover, the state did not grant a charter to a partnership association; its privileges rested entirely on the statement submitted at the time of registration. Because a corporation was a chartered entity, its "existence and ability to contract [could not] be questioned" in a suit brought against a corporation for payment of a debt. But the legitimacy of a partnership association rested on the truthfulness of its filing. As a result, it was "competent" for a plaintiff suing for payment of a debt "either to point to a fatal defect" in the statement "or to prove that an essential requisite, though formally stated, is falsely stated.",52

This type of pro-creditor judicial reasoning had earlier, in Pennsylvania and elsewhere, severely curtailed the appeal of the limited-partnership form by increasing the risk that limited partners would be held fully liable as general partners for their firm's debts. ${ }^{53}$ The lower court judge who tried the Keystone Boot and Shoe case made a valiant attempt to prevent the partnership-association form from suffering the same fate. Counsel for the plaintiffs had cited the case law on the earlier form in support of their claim that the members of Keystone Boot and

\footnotetext{
${ }^{52}$ Eliot v. Himrod, 108 Pa. 569 (1885) at 580.

${ }^{53}$ A key Pennsylvania case was Andrews v. Schott, 10 Pa. 47 (1848).
} 
Shoe Company, Limited should be considered general partners who were individually liable for the company's debts. But the judge did not accept this line of reasoning, instead ruling that the 1836 enabling act for limited partnerships was so different from the 1874 act for partnership associations, "that the decisions under the former are not to be taken as conclusive of the rights and liability of the parties under the latter Act." For example, the 1836 act explicitly listed a set of circumstances in which failure to conform to the terms of the statute would cause limited partners to be held fully liable, but the 1874 statute included no similar provisions. "We must presume," the judge declared, "that the Act of 1836 and the decisions under it were well known to the law-makers at the time the Act of 1874 as passed," so the omission of similar penalties "is good reason for concluding that no such liability was intended." The 1874 act authorized the formation of partnership associations in which the capital subscribed "shall alone be liable for the debts of the association except under certain circumstances," and the judge pointed out, "in no instance do the excepted circumstances impose a liability as general partners on the members of the association.. ${ }^{54}$ The Pennsylvania Supreme Court, however, reversed the judge's decision on appeal. The high-court justices acknowledged that the Act of 1874 bore "little resemblance to the Act of 1836" and was far less stringent in its terms. Rushing to the defense of creditors, however, they insisted "that the statute demands a true statement of capital" at the time of registration, because the filing is what informs the public "of the strength of the association." 55

This idea that creditors could rely on the initial statement of capital for information about the credit worthiness of companies that potentially lasted twenty years is dubious to say the least and certainly formed no part of the jurisprudence on corporations, even though corporate capital

\footnotetext{
${ }^{54}$ Eliot v. Himrod, 108 Pa. 569 (1885).

${ }^{55}$ Eliot v. Himrod, 108 Pa. 569 (1885) at 579.
} 
could also be paid in real or personal estate. ${ }^{56}$ Nonetheless, the Pennsylvania Supreme Court enforced this principle increasingly stringently in a series of decisions holding members of partnership associations liable for their company's debts. ${ }^{57}$ Most of the opinions were written by James P. Sterrett, an upright Republican judge from Alleghany County, who first joined the court in 1877 (Jordan 1921, 153-56). The composition of the court seems to have shifted in Sterrett's favor during the late 1880s with four new justices (out of a total of seven) elected in 1887 and 1888. Three were Republicans and one was a Democrat. ${ }^{58}$ Two of the justices leaving the court had dissented in the first case holding members of a partnership association unlimitedly liable because of a defective filing. ${ }^{59}$ With them gone, Sterrett faced little opposition to his strict construction of the statute. The court began rigorously to assess registration filings to determine whether creditors could "form any estimate of its quantity, character or value," ${ }^{60}$ and the justices showed no compunction about holding members of partnership associations unlimitedly liable as general partners in cases where the statements were insufficiently detailed. Under Sterrett's leadership, the court insisted that property put into an association as capital had to be accurately and fully described. That was more important than valuing it precisely because if the valuation "is excessive, the creditor can decline to give the company credit." By contrast, "if the

\footnotetext{
${ }^{56}$ See Section 17 of Pennsylvania's 1874 general incorporation act.

${ }^{57}$ See Hill, Keiser \& Co. v. Stetler, 127 Pa. 145 (1888); Vanhorn v. Corcoran, 127 Pa. 255 (1889); Sheble v. Strong, 128 Pa. 315 (1889); Gearing v. Carroll, 151 Pa. 79 (1892); Haslet v. Kent, 160 Pa. 85 (1894); First National Bank of Danville v. Creveling, 177 Pa. 270 (1896); and Lee \& Bacchus v. Burnley, 195 Pa. 58 (1900).

${ }^{58}$ See "Historical List of Supreme Court Justices" on the website of the Unified Judicial System of Pennsylvania, http://www.pacourts.us/learn/history/historical-list-of-supreme-court-justices, accessed 24 September 2014. See also Williamson, et al. (1898), 41-43; Blanchard (1900), 943-44; The Twentieth Century Bench and Bar of Pennsylvania (1903), 210-12; and "Williams, Henry W., Assoc. Justice," PA-Roots, http://www.paroots.org/data/read.php?690,502081, accessed 3 Oct. 2014.

${ }^{59}$ See Maloney v. Bruce, 94 Pa. 249 (1880).

${ }^{60}$ Vanhorn v. Corcoran, 127 Pa. 255 (1889) at 266.
} 
description be so defective or inaccurate that the creditor may be misled, he has no means of forming an accurate judgment." ${ }^{, 61}$

As a result of this emphasis on an accurate description of personal estate paid in as capital, the registration documents filed for both limited partnerships and partnership associations grew longer and longer in the early 1890s. The most extreme example was the filing for Wanamaker's department store, a limited partnership, which took up an entire ledger volume and part of a second and seems to have included a complete inventory of the store's goods. But many other registrations went on for scores of pages. ${ }^{62}$ Moreover, even the most painstaking filing was no guarantee against creditors' attempts to pierce the veil, as members of the National Electric Company, Limited, found to their chagrin. At the time of its registration in 1890 , the company had a capital of $\$ 8,500$, most of which had been paid in as items of personal estate. Although the company filed a long inventory that included such detail as 109 8" Flat Porcelain Shades valued at 13 cents each, and 34 boxes of no. 8 screws valued at 35 cents each, the trial judge did not find the inventory sufficiently detailed and ruled in favor of creditors who were suing the members personally to recover a debt. This time, however, the Pennsylvania Supreme Court reversed. Justice J. Brewster McCollum, a Democrat, wrote the opinion. Noting that company's filing "consisted of a hundred and fifty-one items, the integrity and valuation of which were not questioned," he ruled that "this schedule was sufficient to enable parties dealing with the company to readily ascertain the kind, amount and value of the property contributed to

\footnotetext{
${ }^{61}$ Cock v. Bailey, 146 Pa. 328 (1892) at 340. See also Rehfuss v. Moore, 134 Pa. 462 (1890).

${ }^{62}$ The Wanamaker's filing was in Limited Partnership, Vols. 10-11 (LP10-LP11), Partnership Books, 1836-1955, RG 5.23, Philadelphia City Archives. I examined all registrations of limited partnerships and partnership associations filed during every fifth year and found no long inventories before the $1890 \mathrm{~s}$. This time pattern suggests that the already strict construction of the limited partnership statute was becoming even stricter as a result of the litigation over partnership associations.
} 
its capital" and that "the defendants in forming the National Electric Company, Limited, honestly sought to comply with the statutes." 63

In fact, the justices had begun to back away from their extreme position in 1892 , declaring that "[i]t was never intended" that the filing requirements "should be used as a trap to catch persons who have honestly complied with their substantial requisites, and impale them upon a meaningless technicality." ${ }^{, 64}$ But the damage was done. As the cost of filing mounted along with the length of the required descriptions, the popularity of the partnership-association form declined. As Table 2 shows, in Philadelphia use of the form peaked during the 1890s and then dropped precipitously, so that by the 1920s hardly any partnership associations were being registered. ${ }^{65}$ This decline was not likely a result of a lack of desire to form private limited liability companies. When similar types of entities were introduced in Germany and France, they quickly established themselves. Within two decades of the passage of enabling legislation in Germany more than one third of all new firms registered as private limited liability companies, and in France the figure was more than seventy-five percent (Guinnane et al. 2007). Moreover, in the U.S. today, LLCs are quickly becoming the form of choice for the majority of new enterprises, even though the corporate form is much more flexible now than it was in Pennsylvania in the late nineteenth century. ${ }^{66}$

If the partnership association form was so useful, why did contemporary business people not demand that the legislature fix the problem? In part, I think, the answer is that the smallscale enterprises that made the greatest use of the form did not yet constitute an organized

\footnotetext{
${ }^{63}$ See Robbins Electric Co. v. Weber, 172 Pa. 635 (1896) at 644-45.

${ }^{64}$ Cock v. Bailey, 146 Pa. 328 (1892) at 342. See also Laflin \& Rand Co. v. Steytler, 146 Pa. 434 (1892).

${ }^{65} 53$ percent of the partnership associations registered in Philadelphia registrations during the 1892 and 1897 had capital paid in the form of personal or real estate. The proportion fell to 36 percent in 1902 and 1907 . None of the few partnerships registered in the 1920s had capital in this form.

${ }^{66}$ For the number of registrations of LLCs relative to corporations in each state, see the International Association of Commercial Administrators, Annual Report of Jurisdictions.
} 
interest group capable of lobbying for changes in the law. It would not be until the second half of the twentieth century, when high income-tax rates encouraged them to make common cause, that small businesses would join together and lobby for changes in the menu of organizational forms (Lamoreaux 2004). Another part of the answer is federalism. Only a small number of states followed Pennsylvania's lead and passed enabling legislation for the partnershipassociation form: Virginia in 1874, Michigan in 1877, New Jersey in 1880, and Ohio in 1881 (Warren 1929, Stransky 1956, Schwartz 1965, Gazur and Goff 1991). There was consequently a great deal of uncertainty about how partnership associations would be treated by courts in other states. An 1897 case in which a Massachusetts court held a Pennsylvania partnership association to be an ordinary partnership helped kill off interest in the form. ${ }^{67}$

The corporate charter-mongering competition that developed at the end of the nineteenth century in response to the rise of large-scale business enterprises also undercut the partnershipassociation form (Chandler 1977, Lamoreaux 1985). Before this rivalry erupted in the 1890s, nearly all corporations obtained charters from the states in which they originated. New Jersey's famous amendments to its general incorporation laws in 1888 and 1889 broke the pattern. Under existing state laws corporations generally could not own stock in other companies, and two corporations could merge only if one of them dissolved and the other purchased its assets. The New Jersey revisions not only created a streamlined process for mergers but facilitated the creation of holding companies by allowing one corporation to own shares in another (Grandy 1989). Over the next two decades, most of the enterprises involved in the period's successively larger waves of mergers switched to New Jersey charters, and the state, which taxed corporations on the basis of their authorized capital stock, found its revenues soaring. New Jersey's flush treasury inspired a number of other states (most notably Delaware, but also West Virginia,

\footnotetext{
${ }^{67}$ Edwards v. Warren Linoline \& Gasoline Works, 168 Mass. 564 (1897).
} 
Maryland, Maine, and New York) to compete for the business of chartering corporations by enacting still more liberal laws (Butler 1985, Grandy 1989).

Although the literature has focused on the advantages of New Jersey's amendments for consolidations formed by merger, the charter-mongering competition also highlighted other benefits of New Jersey's general incorporation laws. Like Pennsylvania, New Jersey had revised its generation incorporation law in the mid-1870s in response to a new constitutional ban on special charters (Cadman 1849). New Jersey's general incorporation act was much less restrictive, however. It allowed corporations to be formed for any lawful purpose and placed no limits on the amount of capital they could raise, the sums they could borrow, or the acreage of real estate they could own. Incorporators also had more freedom to shape the governance structure of their companies. The act included a number of default rules, but the certificate, charter, or by-laws could specify alternatives. For example, each member of a corporation had one vote for each share owned, unless otherwise specified (Section III. 38). The quorum for stockholders' meetings was a majority of the shares, unless the bylaws indicated otherwise (Section II. 21). Similarly, although the New Jersey law required a two-thirds vote to increase a corporation's capital beyond the amount specified in its certificate, issue a new class of preferred shares, or voluntarily dissolve the corporation, the certificate could specify a different voting threshold to move into a new line of business or decrease capitalization (Section II. 33). More significantly, the certificate could include "any limitation upon the powers of the corporation, the directors, and the stockholders that the parties signing the same desire," so long as these limitations did not "attempt to exempt the corporation, the directors, or the stockholders, from the performance of any duty imposed by law" (Section V). Hence large corporations in Pennsylvania or elsewhere that wanted more contractual flexibility than their state allowed could 
take out charters in New Jersey instead. There was no need any longer to battle their legislatures for more permissive laws. ${ }^{68}$

\section{Pennsylvania in Comparative Perspective}

Before its foray into corporate charter mongering, New Jersey's nineteenth-century political history had much in common with Pennsylvania's. The state maintained a property qualification for voting until 1807 and a tax qualification until 1844, but these barriers seems to have been quite minimal, and throughout the first half of the century a large fraction of adult white males voted - more even than in Pennsylvania (Engerman and Sokoloff 2005). In New Jersey, as in Pennsylvania, corporations were an ongoing subject of heated debate, and Democrats continually pushed to restrict corporate privileges and level the economic playing field. At the 1844 state constitutional convention, they failed to secure a provision requiring a two-thirds super majority in the legislature to charter corporations, but the general incorporation law for manufacturing that the legislature enacted in 1846 was highly restrictive. By 1849 , however, the political balance in the state shifted and the legislature rewrote the law. Although the revised statute still included a number of restrictive provisions (see Table 1), it was generally more permissive than that of neighboring states, and the gap would grow again in 1875 when the legislature responded to a constitutional ban on special charters by passing a new general incorporation law (Cadman 1949, Harris and Lamoreaux 2010).

The famous 1888-89 amendments seem to have an opportunistic response to a tax problem rather than a logical extension of the trend toward permissivness. Before the Civil War, the New Jersey's residents paid almost no property taxes, and levies on railroad corporations

\footnotetext{
${ }^{68}$ For the text of the act, see Corbin (1881).
} 
constituted the bulk of the state's revenues. The state emerged from the war with a large burden of bonded debt which the railroads resisted assuming in a variety of ways, including merging with corporations chartered elsewhere (Grandy 1989). Astute contemporaries seem to have noticed that the more liberal provisions of New Jersey's general incorporation laws were inducing a growing trickle of firms to take out charters in the state (Yablon 2007). Corporate attorney James Brooks Dill, in particular, saw that there was money to be made increasing this flow. Dill helped to guide the amendments through the legislature and then actively promoted the advantages of a New Jersey charter, setting up a new firm, The Corporation Trust Company, to handle the paper work of companies headquartered outside the state and to serve as their legal representatives in New Jersey. Dill's efforts paid off handsomely both for himself and for the state of New Jersey. Combinations that had previously resorted to the trust device now took out New Jersey charters, as did virtually all of the giant consolidations formed during the merger waves of the period. Much of this business, as well as that of other firms flocking to New Jersey, went through Dill's firm. At the same time, tax revenues soared. By the end of the so-called Great Merger Movement in 1904, fully 60 percent of New Jersey’s income came from incorporation fees and franchise taxes. Not only did New Jersey's budget move from deficit to surplus, but the state was able completely to pay off its bonded debt and abolish property taxes on its citizens (Grandy 1989, Yablon 2007).

New Jersey's success in luring the charters of many of the nation's largest businesses stimulated a backlash within the state - a resurgence of anti-corporate politics - that helped elect Democratic candidate Woodrow Wilson governor in 1910 and climaxed with the passage of a set of antitrust statutes in 1913 that effectively undid the liberal amendments of the late 1880s. The state's revenues from chartering corporations immediately plunged, and the legislature reversed 
course again. But the damage was done. The state never regained its previous position, and Delaware emerged victorious from the charter-mongering competition (Grandy 1989, Rutledge 1937, Wells 2000).

Delaware's rise to be the domicile of choice for the nation's largest businesses could never have been predicted from its nineteenth-century political history. Like Pennsylvania, Delaware had broadened its franchise in the late eighteenth century by shifting from a property to a tax qualification for voting (Engerman and Sokoloff 2005). As in Pennsylvania, moreover, opposition to corporate privileges was an important issue around which the new mass democratic movements of the early nineteenth century formed. If anything, these movements were stronger in Delaware than in Pennsylvania or New Jersey at the same time, and Democrats in Delaware succeeded where their counterparts in the other two states had failed, securing a tough constitutional provision requiring a two-thirds vote in both houses of the legislature to charter a corporation. ${ }^{69}$ Delaware did not even enact a general incorporation law until an amendment to the state's constitution in 1875 specially authorized one, and even then the procedure the legislature set up was so cumbersome that few businesses took advantage of it and instead turned to paid lobbyists (and perhaps bribery) to get special charters through the legislature. ${ }^{70}$ Delaware's permissive 1899 general incorporation law was thus for all practical purposes its first. Enacted in response to a ban on special charters embodied in the state's new 1897 constitution (itself a response to what was perceived to be the corruption of the legislative process), it seems to have been shepherded through the legislature by a group of individuals alert

\footnotetext{
${ }^{69}$ Such a measure was repeatedly proposed by delegates to Pennsylvania's 1837 constitutional convention but did not succeed. See, for example, Pennsylvania 1837, Vol. 2, 224-25. As noted above, a similar measure also failed in New Jersey.

${ }^{70}$ Under Delaware's 1875 general incorporation law the application for a charter had to be filed with the local county judge and notice of the filing published for three weeks in a newspaper. The judge then determined whether the application was lawful and the corporation not injurious to the community. If the decision was positive, another period of public notice followed before the ruling could take effect. An 1883 revision of the law streamlined the process somewhat but still required the local judge's approval. See Arsht (1976).
} 
to the revenue possibilities of charter mongering, as well as to the profits that could be earned by serving as local agents for out-of-state corporations. It essentially copied the New Jersey statute but charged lower fees, and the resulting flow of revenues changed the course of the state's corporate politics permanently. In contrast to New Jersey's experience, anti-corporate forces in Delaware never regained the upper hand (Arsht 1976, Larcom 1937, Grandy 1989).

As more and more large firms took out charters in New Jersey, Delaware, and the other charter mongering states, legislatures elsewhere reacted to the resulting loss of revenue by liberalizing their own general incorporation statutes, generating fears of a regulatory race to the bottom (U.S. Commissioner of Corporations 1904). This response, however, was less fullthrottled than is generally recognized..$^{71}$ Some states, it is true, responded by undertaking complete revisions of their statutes. Massachusetts, for example, created a special commission in 1902 that concluded that Massachusetts's general incorporation law was unsuited to modern business conditions (Massachusetts 1903a). The commissioners drafted a completely new statute which the legislature adopted in 1903 almost as proposed (Massachusetts 1903b). The act eliminated a number of the old law's most prescriptive features, including ceilings on the amount of capital a corporation could raise, but it retained other restrictions that provided more substantial protection for shareholders than Delaware's law (Dodd 1936).

Other states (Pennsylvania is a good example) did not undertake a complete revision of their general incorporation statutes until much later, instead meeting the charter mongerers' challenge with a series of amendments that gradually moved the law in the new direction. For example, a supplement to Pennsylvania's 1874 law passed in 1901 authorized a corporation “to

\footnotetext{
${ }^{71}$ Only small states like Delaware could cut incorporation fees and still gain enough revenue relative to their needs to make it worthwhile to compete for charters. Moreover, corporations that shifted their domiciles to Delaware did not also move their production facilities, so the cost of losing the charter-mongering competition was relatively low. See Carruthers and Lamoreaux (2013).
} 
buy and own the capital stock of, and to merge its corporate rights, powers and privileges with and into those of, any other corporation." ${ }^{72}$ Another amendment removed all ceilings on the capital or indebtedness of corporations chartered in the state. ${ }^{73}$ However, most other features of the 1874 statute remained in effect until Pennsylvania finally adopted a new general incorporation law in 1933. Only then did the state give up the practice of listing the types of businesses that could avail themselves of the law, eliminating most, but not all, of the special regulations imposed on different industries. But even then, the act retained a number of governance prescriptions, including the requirement, still mandated by the state constitution, that shareholders be permitted to cumulate their votes when electing directors. ${ }^{74}$

When states revised their general incorporation statutes, moreover, they often deliberately distinguished them in important respects from Delaware's (Wells 2000). Illinois touted its 1933 law as offering superior safeguards for investors (Dodd 1936, Wells 2000), and the committee that drafted the Model Business Corporation Act based its 1946 prototype on the Illinois statute, bragging that "not a single member of the committee thought it desirable to use the Delaware statute as a pattern" (Campbell 1956, 100). However, the model act was in some ways more permissive than the Illinois statute. In particular, it eschewed one of the Illinois law's most restrictive features - a prohibition against the creation of shares with limited voting rights that derived from the legislature's interpretation of a provision in the Illinois constitution (Campbell $1956,101)$.

\footnotetext{
72 "AN ACT Supplementary to an act, entitled 'An act to provide for the incorporation and regulation of certain corporations,' approved the twenty-ninth day of April, one thousand eight hundred and seventy-four; providing for the merger and consolidation of certain corporations," 29 May 1901.

73 "AN ACT To amend section one of the act, entitled 'An act to provide for increasing the capital stock and indebtedness of corporations,' approved the ninth day of February, Anno Domini one thousand nine hundred and one; authorizing corporations to increase their capital stock and indebtedness ...” 22 April 1905. For other changes, see Whitworth and Miller (1902 and 1905).

74 “AN ACT Relating to business corporations ...” 5 May 1933. See also Pennsylvania (1931).
} 
Decades after New Jersey's opening salvo in the charter-mongering competition, the general incorporation statutes of Pennsylvania, Illinois, and other states retained important vestiges of the anti-corporate politics of the nineteenth century, often in the form of restrictions on corporate governance that had been written into their constitutions. Even Delaware's statutes struck observers as much more prescriptive than British company law at the same time. As Gower noted when he visited the U.S. in the 1950s, "To an Englishman it seems strange that corporate codes, such as that of Delaware, which are notoriously lax in failing to provide important safeguards against abuses, should nevertheless be strict in matters which seem to us to be essentially for the parties themselves to settle." British law was contractual to the core. Whereas "the British Companies Act ... [provides] a standard form which applies only in the absence of contrary agreement by the parties," the American statutes "tend to lay down mandatory rules" and, as a result, are "much less flexible" (Gower 1956, 1372,1376-77).

These differences mattered. Gower's complaint about the lack of safeguards in the Delaware statute notwithstanding, the flexibility of British company law allowed corporations to disenfranchise shareholders to an extent that was inconceivable in the U.S., even in Delaware. Timothy Guinnane, Ron Harris, and I have collected the articles of association filed by three random samples of British companies (from 1892, 1812, and 1927 respectively) to observe how incorporators used the contractual freedom that British company granted them (Guinnane, Harris, and Lamoreaux 2014). We found a growing tendency over time for British companies to write rules that isolated the directors from shareholders' oversight. In most companies, for example, directors obtained the power to name one or more of their number "managing directors" who did not have to stand for election by the shareholders during their term of service. Moreover, an increasing proportion of the companies (fully half of the firms in the 1927 sample) 
named in their articles one or more permanent directors who never had to stand for election. ${ }^{75} \mathrm{~A}$ good example is Dymock's Patent Twine Company, Limited, registered in 1912. Clause 21 of the company's articles of association specified that it would have two to five directors. Clause 22 named three of them (a majority), declaring that they "shall be permanent Directors of the Company, and each of them shall be entitled to hold such office so long as he shall live" and meet certain basic qualifications. The articles then went on to lay out procedures that allowed the men's executors to choose successors in the event of their death, again without needing to secure shareholders' approval. ${ }^{76}$

How much power shareholders in corporations should have over management is a hotly debated issue to the present day. Scholars from both ends of the political spectrum have advocated shifting the balance toward shareholders - one side on democratic grounds, and the other on the principle that companies should be run in the interest of their shareholders. ${ }^{77}$ But others have argued that too much shareholder control leads to pressure for short-term gains that discourages executives from developing firm-specific human capital and, more generally, is detrimental to innovation. ${ }^{78}$ Whatever the merits of these different views, I would suggest that the balance of power between shareholders and directors in corporations has been determined more by political forces in the larger society than by any dispassionate assessment of these ideas (on this point, see also Roe 1994). In particular, the early achievement of universal (white) manhood suffrage in the United States shaped the evolution of corporate law in a way that gave

\footnotetext{
${ }^{75}$ James Foreman-Peck and Leslie Hannah (2013) have argued that British companies that traded on the London Stock Exchange voluntarily adopted more stringent governance rules to attract external investment, but they do not check this contention by examining systematically the provisions of the companies' articles of association. Reports from the period in the Financial Times and the Economist suggest that shareholders were effectively disenfranchised in many listed firms as well. See Guinnane, Harris, and Lamoreaux (2014).

${ }^{76}$ Company \#124849, BT 31, Board of Trade: Companies Registration Office: Files of Dissolved Companies, National Archives, Kew, United Kingdom.

${ }^{77}$ The literature ranges from Berle and Means (1932) and Bebchuk (2007) to La Porta, et al. (1997 and 1998) and Baker and Smith (1998).

${ }^{78}$ See, for examples, Stout (2007) and Lazonick (2007).
} 
American shareholders at least on paper considerably more power in corporations than their counterparts in Britain (and elsewhere in Europe) in the nineteenth and early twentieth centuries. Intriguingly, the spread of the franchise in Britain ultimately reversed the shift in power away from shareholders that occurred in the late nineteenth and early twentieth centuries. ${ }^{79}$ Although the change took a long time, when the Labour Party finally gained control of the government in the years following World War II, it not only nationalized some of Britain's largest corporations but enacted a revised Companies Act that gave shareholders the power to dismiss directors by a simple majority vote. Scholars have recently touted this provision as granting shareholders in Britain extraordinary power to discipline directors (Bruner 2013, Nolan 2006, Cheffins 2008), but it is important to recognize the extent to which this law was a product of the new mass democratic politics of the twentieth century. ${ }^{80}$

To reiterate, the early achievement of universal (white) manhood suffrage in the U.S. shaped American corporation law in an exceptional way. I have developed this argument by focusing on the case of Pennsylvania, where a powerful political movement formed in the early nineteenth century around opposition to the special privileges the legislature had granted to corporations. One result of the movement's success was the early adoption of general incorporation laws, but another was the implanting in those laws of a number of restrictions on what corporations could do and how they could be governed. Businesses attempted to escape these restrictions by lobbying the legislature for special charters. This practice, however, only ensured that corporate privileges would continue to be a hot-button political issue until the constitution finally outlawed private charters in 1873. Pennsylvania's general incorporation laws

\footnotetext{
${ }^{79}$ The percent of the adult male population that was formally enfranchised trended up to about 75 percent in the last third of the century and then reached nearly 100 percent after World War I. Before the Great War, however, less than 30 percent of adult males actually voted. See Flora et al. (1983).

${ }^{80}$ Similar changes in the political environment in Germany led to requirement of labor representation on corporate boards. See O’Sullivan (2001) and Roe (1994).
} 
nonetheless remained highly prescriptive, and an attempt to make an end run around the restrictions in the form of an enabling statute for partnership associations, an early form of LLC, ran afoul of a court system whose vigilant defense of creditors' rights was another consequence of the democratic politics of the nineteenth century.

The general outlines of the Pennsylvania story were essentially the same as those of other U.S. states, but political pressures played out in each case in ways that varied according to local circumstances. As a consequence, although general incorporation statutes in the U.S. were on the whole much more prescriptive than in Britain, they were still quite heterogeneous in the extent and type of the rules they imposed. Although it is beyond the scope of this essay to analyze the determinants of these differences and how they came to shape the evolution of the law, I would caution against approaching the problem simply by running cross-state regressions that include a measure of the early extent of the franchise on the right-hand side. As the different histories of Pennsylvania, New Jersey, and Delaware's general incorporation statutes suggest, initial conditions may bound the set of likely outcomes, but they are not fate.

\section{References:}

Acemoglu, Daron, Simon Johnson, and James A. Robinson. 2001. "The Colonial Origins of Comparative Development: An Empirical Investigation.” American Economic Review 91 (December): 1369-1401.

Adams, Sean P. 2006. "Promotion, Competition, Captivity: The Political Economy of Coal." Journal of Policy History 18 (issue 1): 74-95.

Adams, Sean Patrick. 2012. "Soulless Monsters and Iron Horses: The Civil War, Institutional Change, and American Capitalism." In Capitalism Takes Command: The Social Transformation of Nineteenth-Century America, ed. Michael Zakim and Gary J. Kornblith, 249-76. Chicago: University of Chicago Press. 
Akagi, Roy H. 1924. “The Pennsylvania Constitution of 1838.” Pennsylvania Magazine of History and Biography 48 (issue 4): 301-33.

Alesina, Alberto, Paola Giuliano, and Nathan Nunn. 2013. "On the Origins of Gender Roles: Women and the Plough.” Quarterly Journal of Economics 128 (May): 469-530.

Aron, Stephen. 1992. "Pioneers and Profiteers: Land Speculation and the Homestead Ethic in Frontier Kentucky." Western Historical Quarterly 23 (May): 179-98.

Arsht, S. Samuel. 1976. "A History of Delaware Corporation Law." Delaware Journal of Corporate Law 1 (issue 1): 1-22.

Baker, George P., and George David Smith. 1998. The New Financial Capitalists: Kohlberg Kravis Roberts and the Creation of Corporate Value. New York: Cambridge University Press.

Balleisen, Edward J. 2001. Navigating Failure: Bankruptcy and Commercial Society in Antebellum America. Chapel Hill: University of North Carolina Press.

Barro, Robert J. 1997. Determinants of Economic Growth: A Cross-Country Empirical Study. Cambridge, Mass.: MIT Press.

Barro, Robert J., and Rachel M. McCleary. 2003. "Religion and Economic Growth across Countries." American Sociological Review 68 (October): 760-81.

Bebchuk, Lucian A. 2007. "The Myth of the Shareholder Franchise." Virginia Law Review 93 (May): 675-732.

Berle, Adolf A., and Gardiner C. Means. 1932. The Modern Corporation and Private Property. New York: Macmillan.

Blanchard, Charles, ed., 1900. The Progressive Men of the Commonwealth of Pennsylvania. Logansport, Ind.: A. W. Bowen \& Co., Vol. 2.

Bloom, David E., and Jeffrey D. Sachs. 1998. "Geography, Demography, and Economic Growth in Africa." Brookings Papers on Economic Activity 1998 (issue 2): 207-73.

Bodenhorn, Howard. 2002. State Banking in Early America: A New Economic History. New York: Cambridge University Press.

Bodenhorn, Howard. 2006. "Bank Chartering and Political Corruption in Antebellum New York: Free Banking as Reform." In Corruption and Reform: Lessons from America's Economic History, eds. Edward L. Glaeser and Claudia Goldin, 231-57. Chicago: University of Chicago Press. 
Bridge, James Howard. 1903. The Inside Story of the Carnegie Steel Company: A Romance of Millions. New York: Aldine Book Co.

Bruner, Christopher M. 2013. Corporate Governance in the Common-Law World: The Political Foundations of Shareholder Power. Cambridge, Eng.: Cambridge University Press.

Butler, Henry N. 1985. "Nineteenth-Century Jurisdictional Competition in the Granting of Corporate Privileges." Journal of Legal Studies 14 (January): 129-66.

Cadman, John W., Jr. 1949, The Corporation in New Jersey: Business and Politics, 1791-1875. Cambridge, Mass.: Harvard University Press.

California, State of. 1850. Statutes of California, Passed at the First Session of the Legislature. San Jose: J. Winchester.

Campbell, Bruce A. 1975. "John Marshall, the Virginia Political Economy, and the Dartmouth College Decision.” American Journal of Legal History 19 (January): 40-65.

Campbell, Whitney. 1956. "The Model Business Corporation Act.” Business Lawyer 11 (July): 98-110.

Carruthers, Bruce G., and Naomi R. Lamoreaux. 2013. "Regulatory Races: The Effects of Jurisdictional Competition on Regulatory Standards." Unpublished paper.

Chandler, Alfred D., Jr. 1977. The Visible Hand: The Managerial Revolution in American Business. Cambridge, Mass.: Harvard University Press.

Cheffins, Brian R. 2008. Corporate Ownership and Control: British Business Transformed. Oxford, Eng.: Oxford University Press.

Corbin, William H. 1881. The Act Concerning Corporations in the State of New Jersey Approved April 7, 1875 with all the Amendments to January 1, 1881. Jersey City, N.J.: Frederick D. Linn \& Co.

de Soto, Hernando. 2000. The Mystery of Capital: Why Capitalism Triumphs in the West and Fails Everywhere Else. New York: Basic Books.

Dodd, E. Merrick, Jr. 1936. "Statutory Developments in Business Corporation Law, 18861936." Harvard Law Review 50 (November): 27-59.

Eastman, Frank M. 1908. A Treatise on the Law Relating to Private Corporations in Pennsylvania. $2^{\text {nd }}$ edn.; Philadelphia: George T. Bisel Co., 2 vols.

Elmer, Lucius Q. C. 1855. A Digest of the Laws of New Jersey: Containing All the Laws of General Application, Now in Force, from 1709 to 1855, Inclusive, with the Rules and Decisions of the Courts. $2^{\text {nd }}$ edn.; Philadelphia: J. B. Lippincott \& Co. 
Engerman, Stanley L., and Kenneth L. Sokoloff. 2005. "The Evolution of Suffrage Institutions in the New World." Journal of Economic History 65 (December): 891-921.

Engerman, Stanley L., and Kenneth L. Sokoloff. 2011. Economic Development in the Americas since 1500: Endowments and Institutions. New York: Cambridge University Press.

Flora, Peter, et al. 1983. State, Economy, and Society in Western Europe, 1815-1975, Vol. 1: The Growth of Mass Democracies and Welfare States. Frankfurt: Campus Verlag.

Foreman-Peck, James, and Leslie Hannah. 2013. "Some Consequences of the Early TwentiethCentury British Divorce of Ownership from Control.” Business History 55 (issue 4): 543-64.

Freedley, Angelo T. 1883. The Limited Partnership Association Laws of Pennsylvania, with Notes, Forms and Index. Philadelphia: T. \& J. W. Johnson \& Co.

Freeman, Mark, Robin Pearson, and James Taylor. 2011. Shareholder Democracies? Corporate Governance in Britain and Ireland before 1850. Chicago: University of Chicago Press.

Gallup, John Luke, Jeffrey D. Sachs, and Andrew D. Mellinger. 1999. "Geography and Economic Development." International Regional Science Review 22 (August): 179-232.

Gates, Paul W. 1962. "Tenants of the Log Cabin.” Mississippi Valley Historical Review 49 (June): 3-31.

Gazur, Wayne M., and Neil M. Goff.” 1991. "Assessing the Limited Liability Company.” Case Western Reserve Law Review 41 (issue 2): 387-501.

Gower, L. C. B. 1956. "Some Contrasts between British and American Corporation Law." Harvard Law Review 69 (June): 1369-1402.

Grandy, Christopher. 1989. "New Jersey Corporate Chartermongering, 1875-1929." Journal of Economic History 49 (September): 677-92.

Grubb, Farley. 2003. "Creating the U.S. Dollar Currency Union, 1748-1811: A Quest for Monetary Stability or a Usurpation of State Sovereignty for Personal Gain?" American Economic Review 93 (Dec. 2003): 1778-98.

Guinnane, Timothy W., Ron Harris, and Naomi R. Lamoreaux. 2014. "Contractual Freedom and the Evolution of Corporate Governance in Britain, 1862 to 1929." NBER Working Paper 20481 (September).

Guinnane, Timothy W., Ron Harris, Naomi R. Lamoreaux, and Jean-Laurent Rosenthal. 2007. "Putting the Corporation in its Place." Enterprise and Society 8 (September): 687-729. 
Hamill, Susan Pace. 1999. "From Special Privilege to General Utility: A Continuation of Willard Hurst's Study of Corporations." American University Law Review 49 (October): 81180.

Hammond, Bray. 1957. Banks and Politics in America: From the Revolution to the Civil War. Princeton, N.J.: Princeton University Press.

Handlin, Oscar, and Mary Flug Handlin. 1969. Commonwealth: A Study of the Role of Government in the American Economy. Rev. edn.; Cambridge: Harvard University Press.

Harlan, A. D. 1873. Pennsylvania Constitutional Convention 1872 and 1873: Its Members and Officers and the Result of their Labors. Philadelphia: Inquirer Book and Job Print.

Harris, Ron. 2000. Industrializing English Law: Entrepreneurship and Business Organization, 1720-1844. Cambridge: Cambridge University Press.

Harris, Ron, and Naomi R. Lamoreaux. 2010. "Contractual Flexibility within the Common Law: Organizing Private Companies in Britain and the United States." Unpublished paper.

Hartz, Louis. 1948. Economic Policy and Democratic Thought: Pennsylvania, 1776-1860. Cambridge, Mass.: Harvard University Press.

Hennessey, Jessica L., and John Joseph Wallis. 2014. “Corporations and Organizations in the United States after 1840.” Unpublished paper.

Hilt, Eric. 2013. "General Incorporation Acts for Manufacturing Firms, 1811-1860.” Unpublished paper.

Hilt, Eric, and Katharine O’Banion. 2009. “The Limited Partnership in New York, 1822-1858: Partnerships Without Kinship.” Journal of Economic History 69 (September): 615-45.

Hilt, Eric, and Jacqueline Valentine. 2012. "Democratic Dividends: Stockholding, Wealth, and Politics in New York, 1791-1826.” Journal of Economic History 72 (June): 332-63.

Howard, Stanley E. 1934. "The Limited Partnership in New Jersey." Journal of Business of the University of Chicago 7 (October): 296-317.

Hurst, James Willard. 1970. The Legitimacy of the Business Corporation in the Law of the United States, 1780-1970. Charlottesville: University Press of Virginia.

Illinois, State of. 1857. Laws of the State of Illinois, Passed by the Twentieth General Assembly Convened January 5, 1857. Springfield: Lanphier \& Walker.

Jordan, John W. 1921. Encyclopedia of Pennsylvania Biography. New York: Lewis Historical Publishing Co. 
Kessler, Amalia D. 2003. "Limited Liability in Context: Lessons from the French Origins of the American Limited Partnership." Journal of Legal Studies 32 (June): 511-48.

Kessler, W. C. 1940. "A Statistical Study of the New York General Incorporation Act of 1811." Journal of Political Economy 48 (December): 877-82.

Keyssar, Alexander. 2000. The Right to Vote: The Contested History of Democracy in the United States. New York: Basic Books.

Kutler, Stanley I. 1971. Privilege and Creative Destruction: The Charles River Bridge Case. Philadelphia: Lippincott.

Lamoreaux, Naomi R. 1985. The Great Merger Movement in American Business, 1895-1904. New York: Cambridge University Press.

Lamoreaux, Naomi R. 1994. Insider Lending: Banks, Personal Connections, and Economic Development in Industrial New England. New York: Cambridge University Press.

Lamoreaux, Naomi R. 1997. “The Partnership Form of Organization: Its Popularity in EarlyNineteenth-Century Boston.” In Entrepreneurs: The Boston Business Community, 17501850, eds. Conrad E. Wright and Katheryn P. Viens, 269-95. Boston: Massachusetts Historical Society.

Lamoreaux, Naomi R. 2004. "Partnerships, Corporations, and the Limits on Contractual Freedom in U.S. History: An Essay in Economics, Law, and Culture." In Constructing Corporate America: History, Politics, and Culture, eds. Kenneth Lipartito and David B. Sicilia, 29-65. New York: Oxford University Press.

Lamoreaux, Naomi R. 2011. “The Mystery of Property Rights: A U.S. Perspective.” Journal of Economic History 71 (June): 275-306.

Lamoreaux, Naomi R., and Jean-Laurent Rosenthal. 2005. "Legal Regime and Contractual Flexibility: A Comparison of Business's Organizational Choices in France and the United States during the Era of Industrialization." American Law and Economics Review 7 (Spring): 28-61.

Lamoreaux, Naomi R., and John Joseph Wallis. 2012. "The Economics of Civil Society." Unpublished paper.

La Porta, Rafael, Florencio Lopez-de-Silanes, and Andrei Shleifer. 2008. "The Economic Consequences of Legal Origins.” Journal of Economic Literature 46 (June): 285-332.

La Porta, Rafael, Florencio Lopez-de-Silanes, Andrei Shleifer, and Robert W. Vishny. 1997. "Legal Determinants of External Finance." Journal of Finance 52 (July): 1131-50. 
La Porta, Rafael, Florencio Lopez-de-Silanes, Andrei Shleifer, and Robert W. Vishny. 1998. "Law and Finance." Journal of Political Economy 106 (December): 1113-55.

Larcom, Russell Carpenter. 1937. The Delaware Corporation. Baltimore: Johns Hopkins Press.

Lazonick, William. 2007. "The US Stock Market and the Governance of Innovative Enterprise.” Industrial and Corporate Change 16 (December): 983-1035.

Lewis, William Draper. 1917. "The Uniform Limited Partnership Act." University of Pennsylvania Law Review 65 (June): 715-31.

Livesay, Harold C. 1975. Andrew Carnegie and the Rise of Big Business. Boston: Little Brown.

Lu, Qian, and John Wallis. 2013. "Banks, Politics, and Political Parties: From Partisan Banking to Open Access in Early Massachusetts." Unpublished paper.

Maier, Pauline. 1992. "The Debate over Incorporations: Massachusetts in the Early Republic." In Massachusetts and the New Nation, ed. Conrad Edick Wright, 75-81. Boston: Massachusetts Historical Society.

Maier, Pauline. 1993. "The Revolutionary Origins of the American Corporation." William and Mary Quarterly 50 (January): 51-84.

Majewski, John. 2000. A House Dividing: Economic Development in Pennsylvania and Virginia before the Civil War. New York: Cambridge University Press.

Majewski, John. 2006. "Toward a Social History of the Corporation: Shareholding in Pennsylvania, 1800-1840." In The Economy of Early America: Historical Perspectives \& New Directions, ed. Cathy Matson, 294-316. University Park, Penn.: Pennsylvania State University Press.

Massachusetts, Commonwealth of. 1836. The Revised Statutes of the Commonwealth of Massachusetts, Passed November 4, 1835. Boston: Dutton \& Wentworth.

Massachusetts, Commonwealth of. 1854. General Laws of the Commonwealth of Massachusetts Passed Subsequently to the Revised Statutes. Boston: Dutton \& Wentworth.

Massachusetts, Commonwealth of. 1903a. Report of the Committee on Corporation Laws, Created by Acts of 1902, Chapter 335. Boston: Wright \& Potter.

Massachusetts, Commonwealth of. 1903b. Acts and Resolves Passed by the General Court of Massachusetts in the Year 1903. Boston: Wright \& Potter. 
McCleary, Rachel M., and Robert J. Barro. 2006. "Religion and Political Economy in an International Panel.” Journal for the Scientific Study of Religion 45 (June): 149-75.

Murrin, John M. 2000. “The Jeffersonian Triumph and American Exceptionalism.” Journal of the Early Republic 20 (Spring): 1-25.

Nedelsky, Jennifer. 1990. Private Property and the Limits of American Constitutionalism: The Madisonian Framework and Its Legacy. Chicago: University of Chicago Press.

New York, State of. 1821. Reports of the Proceedings and Debates of the Convention of 1821, Assembled for the Purpose of Amending the Constitution. Albany: E. and E. Hosford.

New York, State of. 1848. Laws of the State of New-York Passed at the Seventy-First Session of the Legislature. Albany: Charles Van Benthuysen.

Nolan, R. C. 2006. "The Continuing Evolution of Shareholder Governance.” Cambridge Law Journal 65 (March): 92-127.

North, Douglass C., John Joseph Wallis, and Barry R. Weingast. 2009. Violence and Social Orders: A Conceptual Framework for Interpreting Recorded Human History. New York: Cambridge University Press.

Nunn, Nathan. 2008. “The Long-Term Effects of Africa's Slave Trades.” Quarterly Journal of Economics 123 (February): 139-76.

Nunn, Nathan, and Leonard Wantchekon. 2011 "The Slave Trade and the Origins of Mistrust in Africa." American Economic Review 101 (December): 3221-52.

O’Gorman, Frank. 1993. “The Electorate Before and After 1832.” Parliamentary History 12 (Pt. 2): 171-83.

Ohio, State of. 1846. Acts of a General Nature Passed by the Forty-Fourth General Assembly of the State of Ohio, Begun and Held in the City of Columbus, December 1, 1845.

Columbus: C. Scott and Co.

Onuf, Peter S. 2012. “American Exceptionalism and National Identity.” American Political Thought 1 (Spring 2012): 77-100.

O’Sullivan, Mary. 2001. Contests for Corporate Control: Corporate Governance and Economic Performance in the United States and Germany. New York: Oxford University Press.

Papaioannou, Elias, and Gregorios Siourounis. 2008. "Democratization and Growth." Economic Journal 118 (October): 1520-51. 
Pennsylvania, Commonwealth of. 1810. Laws, Statutes, etc., 1700-1800. 4 vols. Philadelphia: Bioren.

Pennsylvania, Commonwealth of. 1855. Laws of the General Assembly. Harrisburg: A. Boyd Hamilton.

Pennsylvania, Commonwealth of. 1837-38. Proceedings and Debates of the Convention to Propose Amendments to the Constitution. Harrisburg: Packer, Barrett, and Parks. 14 vols.

Pennsylvania, Commonwealth of. 1873. Debates of the Convention to Amend the Constitution of Pennsylvania. Harrisburg: Benjamin Singerly, State Printer. 9 vols.

Pennsylvania, Commonwealth of. 1874a. The Constitution of the Commonwealth of Pennsylvania Adopted December 16, 1873. Harrisburg: Benjamin Singerly, State Printer.

Pennsylvania, Commonwealth of. 1874b. The Legislative Journal for the Session of 1874. Harrisburg: Benjamin Singerly, State Printer. [Available on microfilm at the Pennsylvania State Library in Harrisburg.]

Pennslvania, Commonwealth of. 1931. Proposed Business Corporation Law Prepared by the Department of Justice. Harrisburg: n.p.

Phillips, John A., and Charles Wetherell. 1995. "The Great Reform Act of 1832 and the Political Modernization of England.” American Historical Review 100 (April): 411-36.

Rodrik, Dani, Arvind Subramanian, and Francesco Trebbi. 2004. "Institutions Rule: The Primacy of Institutions over Geography and Integration in Economic Development." Journal of Economic Growth 9 (June): 131-65.

Roe, Mark J. 1994. Strong Managers, Weak Owners: The Political Roots of American Corporate Finance. Princeton: Princeton University Press.

Roe, Mark J., and Jordan I. Siegel. 2009. "Finance and Politics: A Review Essay Based on Kenneth Dam's Analysis of Legal Traditions in The Law-Growth Nexus." Journal of Economic Literature 47 (September): 781-800.

Ross, Dorothy. 1984. "Historical Consciousness in Nineteenth-Century America." American Historical Review 89 (October): 909-28.

Rutledge, Wiley B., Jr. 1937. "Significant Trends in Modern Incorporation Statutes." Washington University Law Quarterly 22 (April): 305-43.

Sachs, Jeffrey D. and Andrew M. Warner. 2001. "The Curse of Natural Resources." European Economic Review 45 (May): 827-38. 
Schocket, Andrew M. 2007. Founding Corporate Power in Early National Philadelphia. DeKalb, Ill. Northern Illinois University Press.

Schwartz, Anna J. 1987. "The Beginning of Competitive Banking in Philadelphia, 1782-1809." In Money in Historical Perspective, ed. Schwartz, 3-23. Chicago: University of Chicago Press.

Schwartz, Edward R. 1965. "The Limited Partnership Association-An Alternative to the Corporation for the Small Business with 'Control' Problems?” Rutgers Law Review 20 (Fall): 29-88.

Seavoy, Ronald E. 1982. The Origins of the American Business Corporation, 1784-1855:

Broadening the Concept of Public Service during Industrialization. Westport, Conn.: Greenwood Press.

Smull, John A. 1874. Rules and Decisions of the General Assembly of Pennsylvania, Legislative Directory, Together with Useful Political Statistics, List of Post Offices, County Officers, \&c. Harrisburg: Benjamin Singerly, State Printer.

Stout, Lynn A. 2007. "The Mythical Benefits of Shareholder Control.” Virginia Law Review 93 (May): 789-809.

Stransky, George E., Jr. 1956. "The Limited Partnership Association in New Jersey.” Rutgers Law Review 10 (Summer): 701-15.

Tarbell, Ida M. 1904. The History of the Standard Oil Company. New York: McClure, Phillips \& Co. 2 vols.

Taylor, James. 2006. Creating Capitalism: Joint-Stock Enterprise in British Politics and Culture, 1800-1870. Woodbridge, Eng.: Royal Historical Society/Boydell.

Thring, Henry. 1856. The Joint Stock Companies Act, 1856: With an Introduction, Practical Notes, and an Appendix of Forms. London: Stevens \& Norton.

The Twentieth Century Bench and Bar of Pennsylvania. 1903. Chicago: H. C. Cooper, Jr., Bro. \& Co., Vol. 1

Tyrrell, Ian. 1991. "American Exceptionalism in an Age of International History." American Historical Review 96 (October): 1031-55.

U.S. Commissioner of Corporations. 1904. "Report." House Doc. $165,58^{\text {th }}$ Cong., $3^{\text {rd }}$ Sess. Washington, DC: Government Printing Office.

Van Atta, John R. 2008. “'A Lawless Rabble': Henry Clay and the Cultural Politics of Squatters' Rights, 1832-1841.” Journal of the Early Republic 28 (Fall): 337-78. 
Wall, Joseph Frazier. 1970. Andrew Carnegie. New York: Oxford University Press.

Wallis, John Joseph. 2005. "Constitutions, Corporations, and Corruption: American States and Constitutional Change, 1842 to 1852." Journal of Economic History 65 (March): 211-56.

Warren, Edward H. 1929. Corporate Advantages without Incorporation: An Examination of the Law Relating to Ordinary Partnerships, Limited Partnerships, Partnership Associations, Joint-Stock Companies, Business Trusts, .... New York: Baker, Voorhis.

Wells, Harwell. 2000. "The Modernization of Corporation Law, 1920-40.” University of Pennsylvania Journal of Business Law 11 (Spring): 573-629.

Wells, William P. 1886. "The Dartmouth College Case and Private Corporations." In Report of the Ninth Annual Meeting of the American Bar Association, 229-56. Philadelphia: Dando.

Whitworth, John F., and Clarence B. Miller. 1902. Statutory Law of Corporations in Pennsylvania, Including Annotations and a Complete Set of Forms. Philadelphia: T. \& J. W. Johnson \& Co.

Whitworth, John F., and Clarence B. Miller. 1905. The Corporation Laws of Pennsylvania, 1903-1905, ..., Being a Supplement to Statutory Law of Corporations. Philadelphia: T. \& J. W. Johnson \& Co.

Williamson, Leland M., et al., eds. 1898. Prominent and Progressive Pennsylvanians of the Nineteenth Century: A Review of their Careers. Philadelphia: Record Publishing Co., Vol. 1.

Yablon, Charles M. 2007. "The Historical Race: Competition for Corporate Charters and the Rise and Decline of New Jersey: 1880-1910.” Journal of Corporation Law 32 (Winter): 323-80. 
Table 1. Restrictions on Manufacturing Corporations in Early General Incorporation Statutes

\begin{tabular}{|l|l|l|l|l|l|l|l|}
\hline State & $\begin{array}{l}\text { Year } \\
\text { of } \\
\text { Statute }\end{array}$ & $\begin{array}{l}\text { Restrictions } \\
\text { on capital } \\
\text { stock }\end{array}$ & $\begin{array}{l}\text { Restrictions } \\
\text { on borrowing } \\
\text { or assets }\end{array}$ & $\begin{array}{l}\text { Restrictions } \\
\text { on duration }\end{array}$ & $\begin{array}{l}\text { Governance } \\
\text { Structure }\end{array}$ & Voting Rule & $\begin{array}{l}\text { Shareholders' } \\
\text { Liability }\end{array}$ \\
\hline Massachusetts & 1851 & $\begin{array}{l}\text { Must be at } \\
\text { least } \$ 5,000 \\
\text { but not more } \\
\text { than } \\
\$ 200,000\end{array}$ & $\begin{array}{l}\text { Debts cannot } \\
\text { exceed paid- } \\
\text { in capital }\end{array}$ & None & $\begin{array}{l}\text { Managed at } \\
\text { least 3 } \\
\text { directors, one } \\
\text { of whom is } \\
\text { president; } \\
\text { must also } \\
\text { elect clerk } \\
\text { and treasurer }\end{array}$ & None & $\begin{array}{l}\text { Stockholders } \\
\text { jointly liable } \\
\text { for all debts } \\
\text { until capital } \\
\text { is fully paid } \\
\text { in; then for } \\
\text { debts to } \\
\text { workers }\end{array}$ \\
\hline New York & 1848 & None & $\begin{array}{l}\text { Debts cannot } \\
\text { exceed } \\
\text { amount of } \\
\text { capital stock }\end{array}$ & 50 years & $\begin{array}{l}\text { Managed by } \\
\text { 3 to 9 } \\
\text { trustees, one } \\
\text { of whom is } \\
\text { president }\end{array}$ & $\begin{array}{l}\text { One vote per } \\
\text { share }\end{array}$ & $\begin{array}{l}\text { Stockholders } \\
\text { individually } \\
\text { liable for } \\
\text { debts up to } \\
\text { amount of } \\
\text { subscription } \\
\text { until capital } \\
\text { is fully paid } \\
\text { in; jointly } \\
\text { liable for } \\
\text { debts to } \\
\text { workers }\end{array}$ \\
\hline New Jersey & 1849 & $\begin{array}{l}\text { Must be at } \\
\text { least } \$ 10,000\end{array}$ & $\begin{array}{l}\text { Debts cannot } \\
\text { exceed paid- } \\
\text { in capital }\end{array}$ \\
\end{tabular}




\begin{tabular}{|c|c|c|c|c|c|c|c|}
\hline & & & & & $\begin{array}{l}\text { majority } \\
\text { must be } \\
\text { residents of } \\
\text { state; } \\
\text { president } \\
\text { must be a } \\
\text { director and } \\
\text { resident of } \\
\text { state }\end{array}$ & & \\
\hline Pennsylvania & 1849 & $\begin{array}{l}\text { Must be at } \\
\text { least } \$ 20,000\end{array}$ & $\begin{array}{l}\text { Liabilities } \\
\text { cannot } \\
\text { exceed three } \\
\text { times paid-in } \\
\text { capital; can't } \\
\text { own more } \\
\text { than } 2000 \\
\text { acres of land }\end{array}$ & 20 years & $\begin{array}{l}\text { Managed by } \\
5 \text { to } 13 \\
\text { directors; } \\
\text { majority } \\
\text { must be } \\
\text { citizens of } \\
\text { state; } \\
\text { president } \\
\text { must be a } \\
\text { director; } \\
\text { treasurer and } \\
\text { secretary } \\
\text { elected by } \\
\text { stockholders } \\
\text { but cannot be } \\
\text { directors }\end{array}$ & $\begin{array}{l}\text { One vote per } \\
\text { share, but no } \\
\text { shareholder } \\
\text { can vote } \\
\text { more than } \\
\text { one third of } \\
\text { total }\end{array}$ & $\begin{array}{l}\text { Stockholders } \\
\text { jointly liable } \\
\text { for amount of } \\
\text { for debts up } \\
\text { to amount of } \\
\text { subscription } \\
\text { until capital } \\
\text { is fully paid } \\
\text { in }\end{array}$ \\
\hline Ohio & 1846 & $\begin{array}{l}\text { Must be at } \\
\text { least } \$ 5,000 \\
\text { but not more } \\
\text { than } \\
\$ 200,000\end{array}$ & None & 40 years & $\begin{array}{l}\text { Managed by } \\
3 \text { to } 7 \\
\text { directors; } \\
\text { president } \\
\text { chosen by } \\
\text { directors }\end{array}$ & $\begin{array}{l}\text { One vote per } \\
\text { share }\end{array}$ & $\begin{array}{l}\text { Stockholders } \\
\text { liability } \\
\text { limited to } \\
\text { amount of } \\
\text { subscription } \\
\text { except are } \\
\text { fully liable } \\
\text { for debts to }\end{array}$ \\
\hline
\end{tabular}




\begin{tabular}{|l|l|l|l|l|l|l|l|}
\hline Illinois & 1857 & $\begin{array}{l}\text { Must be at } \\
\text { least } \$ 10,000 \\
\text { but not more } \\
\text { than } \\
\$ 500,000\end{array}$ & $\begin{array}{l}\text { Debts cannot } \\
\text { exceed the } \\
\text { amount of } \\
\text { capital stock. }\end{array}$ & 50 years & $\begin{array}{l}\text { Managed by } \\
3 \text { to } 7 \\
\text { directors } \\
\text { who must be } \\
\text { stockholders; } \\
\text { directors } \\
\text { choose other } \\
\text { officers }\end{array}$ & $\begin{array}{l}\text { One vote per } \\
\text { share }\end{array}$ & $\begin{array}{l}\text { Stockholders } \\
\text { liable for } \\
\text { debts up to } \\
\text { amount of } \\
\text { subscription } \\
\text { until capital } \\
\text { is fully paid } \\
\text { in }\end{array}$ \\
\hline California & 1850 & None & $\begin{array}{l}\text { Debts cannot } \\
\text { exceed } \\
\text { amount of } \\
\text { paid-in } \\
\text { capital }\end{array}$ & 50 years & $\begin{array}{l}\text { Managed by } \\
\text { 3 to 9 } \\
\text { trustees, one } \\
\text { of whom } \\
\text { chosen } \\
\text { president }\end{array}$ & $\begin{array}{l}\text { One vote per } \\
\text { share }\end{array}$ & $\begin{array}{l}\text { Unlimited } \\
\text { individual } \\
\text { proportional } \\
\text { liability, also } \\
\text { jointly liable } \\
\text { for debts to } \\
\text { workers }\end{array}$ \\
\hline
\end{tabular}

Sources: Massachusetts (1854), Vol. 1, 660-64; Massachusetts (1836), 327-34, 362-66; New York (1848), 54-61; Elmer (1855), 45662; Pennsylvania (1849), 563-69; Ohio (1846), 37-40; Illinois (1857), 161-65; California (1850), 347-76. 
Table 2. Number and Size of Partnership Associations Registered in Philadelphia County, 1877-1927

\begin{tabular}{|c|c|c|c|c|c|c|c|c|}
\hline Year & $\begin{array}{l}\text { Number } \\
\text { of Firms }\end{array}$ & $\begin{array}{c}\text { Percent } \\
\text { with } 3 \\
\text { Owners }\end{array}$ & $\begin{array}{c}\text { Percent } \\
\text { with 4-9 } \\
\text { Owners }\end{array}$ & $\begin{array}{c}\text { Percent } \\
\text { with } 10+ \\
\text { Owners }\end{array}$ & $\begin{array}{c}\text { Average } \\
\text { Capital } \\
\text { in } \$ \$\end{array}$ & $\begin{array}{c}\text { Percent with } \\
\text { Capital } \leq \\
\$ 10,000\end{array}$ & $\begin{array}{c}\text { Percent with } \\
\$ 10,000< \\
\text { Capital }< \\
\$ 100,000\end{array}$ & $\begin{array}{c}\text { Percent with } \\
\text { Capital } \geq \\
\$ 100,000\end{array}$ \\
\hline 1877 & 31 & 45.2 & 45.2 & 9.7 & 113,300 & 35.4 & 38.7 & 25.8 \\
\hline 1882 & 47 & 59.6 & 36.1 & 4.3 & 43,700 & 46.8 & 38.3 & 14.9 \\
\hline 1887 & 59 & 57.6 & 37.3 & 5.1 & 69,600 & 45.8 & 32.2 & 22.0 \\
\hline 1892 & 69 & 69.6 & 29.0 & 1.4 & 111,800 & 56.5 & 37.7 & 5.8 \\
\hline 1897 & 65 & 69.2 & 27.7 & 3.1 & 48,400 & 67.7 & 18.5 & 13.8 \\
\hline 1902 & 30 & 83.3 & 13.3 & 3.3 & 6,400 & 80.0 & 20.0 & 0.0 \\
\hline 1907 & 12 & 75.0 & 16.7 & 8.3 & 8,000 & 83.3 & 16.7 & 0.0 \\
\hline 1912 & 5 & 80.0 & 20.0 & 0.0 & 6,000 & 100.0 & 0.0 & 0.0 \\
\hline 1917 & 0 & na & na & na & 0 & na & na & na \\
\hline 1922 & 1 & 0.0 & 100.0 & 0.0 & 10,000 & 100.0 & 0.0 & 0.0 \\
\hline 1927 & 2 & 50.0 & 50.0 & 0.0 & 2,700 & 100.0 & 0.0 & 0.0 \\
\hline
\end{tabular}

Source: Partnership Books, 1836-1955, RG 5.23, City Archives, City of Philadelphia, Department of Records. 